\title{
Photodynamic Therapy (PDT): An Alternative Approach for Combating COVID-19
}

\author{
Sunil Bhapkar ${ }^{1}$ (D), Navanath Kumbhar ${ }^{2}$ (D), Rajesh Gacche ${ }^{2}$ (i) , Shweta Jagtap ${ }^{3}$ (iD), \\ Umesh Jadhav 1 * *iD
}

1 Department of Microbiology, Savitribai Phule Pune University, Pune, Maharashtra, India; sunilnbh27@gmail.com (S.B.); ujadhav@unipune.ac.in (U.J.);

2 Department of Biotechnology, Savitribai Phule Pune University, Pune, Maharashtra, India; nmkumbhar@gmail.com (N.K.); rngacche@ rediffmail.com (R.G.);

3 Department of Instrumentation Science, Savitribai Phule Pune University, Pune, Maharashtra, India; shweta.jagtap@gmail.com (S.J.);

* Correspondence: ujadhav@unipune.ac.in; umeshjadhav02@gmail.com;

Received: 17.01.2020; Revised: 18.01.2021; Accepted: 22.01.2021; Published: 31.01.2021

\begin{abstract}
The COVID-19 disease initially originated in Wuhan (China) and then spread worldwide has been declared a pandemic by the World Health Organization (WHO). Many attempts are ongoing to find an effective therapeutic treatment and vaccine to cure or prevent the disease, but the success is very little. Even some of the approved vaccines are also disputed for safety issues. This is the time where we should think of alternative treatments to control the disease effectively. Photodynamic therapy (PDT) is a technique that is widely used in cancer treatment and against various microbes. In this technique, a light-induced photosensitizer generates reactive oxygen species (ROS), ultimately killing the target cells. Considering these facts, an attempt has been made to review the current literature on viral inactivation using PDT approach. Accordingly, the mechanism of PDT action has been discussed, along with an update on the use of various photosensitizers (PSs) and nanoparticles. The capsid proteins and nucleic acid (RNA) of SARS-CoV-2 can be a possible target for PDT. To understand this interaction further, computational modeling studies have been discussed to help design effective PSs. Overall, the PDT technique has therapeutic potential and should be tested as a complementary or alternative treatment for control of COVID-19 using the PSs like curcumin, psoralen derivatives, riboflavin, etc. This review discusses COVID-19, its outbreak, diagnosis, the existing treatment modalities, and how PDT can be an effective alternative treatment for controlling the disease.
\end{abstract}

Keywords: COVID-19; photosensitizers; photodynamic therapy; virus inactivation; computational modeling.

(C) 2021 by the authors. This article is an open-access article distributed under the terms and conditions of the Creative Commons Attribution (CC BY) license (https://creativecommons.org/licenses/by/4.0/).

\section{Introduction}

The world has been facing various epidemic diseases for several years. Many of them affected certain regions or countries, while few affected a major part of the globe. Recently reported outbreaks like Zika, Chikungunya, Avian influenza, Ebola, COVID-19, etc., have affected the global network socially and economically (WHO). A recent outbreak of COVID19 (initially named Novel Coronavirus Pneumonia by the Chinese Government was later renamed as COVID-19 by the World Health Organization is the most widespread and has affected the entire world. The disease mainly affects the lower respiratory system [1]. This outbreak is because of the coronavirus named SARS-CoV-2 by the International Committee 
on Taxonomy of Viruses [2]. Bats are possible reservoir hosts of the SARS-CoV-2, and a Bat coronavirus RaTG13 shows $96.2 \%$ sequence identity to the SARS-CoV-2 [3]. However, the way of transmission (whether direct or through any intermediate host) of SAR-CoV-2 to humans still remains unknown [3]. The virus initially originated in Wuhan, China, and spread rapidly. By the end of January 2020, it was declared a global health emergency by WHO [4], and on 11 March 2020, it is declared a pandemic. As of $12^{\text {th }}$ October 2020, the SARS-CoV-2 has infected $>37$ million people and resulted in the death of $>1$ million individuals (WHO). The coronavirus family outbreaks were reported in the past also [1]. WHO reported three main outbreaks of the coronavirus. The information about it is given in Table 1.

Table 1. Coronavirus outbreaks.

\begin{tabular}{l|l|c|c|c|c} 
Sr. No. & Disease & Country of origin & Year & Countries affected & Total cases reported \\
\hline 1 & SARS & China & 2003 & $>26$ & $>8000$ \\
\hline 2 & MERS & Saudi Arabia & 2012 & 27 & 2494 \\
\hline 3 & COVID-19 & China & 2019 & Entire world & $>80$ million
\end{tabular}

Despite various scientific advances like developing new vaccines and immunization for existing human diseases, new viruses continue to pass from their wild host to animals and humans.

\section{SARS-CoV-2 Virus: Structure and Diagnosis}

The SARS-CoV-2 virus particles are spherical and enveloped (size ranges from 80-120 $\mathrm{nm}$ ), having positive-sense ssRNA of size around 30,000 nucleotides [5]. Genetically, SARSCoV-2 shows about $79 \%$ similarity to SARS-CoV and 50\% to MERS-CoV [6]. All the structural and accessory proteins are translated from the virus's single-guide RNAs (sgRNAs) [7]. The genomic RNA is tightly coiled and covered by the nucleocapsid (N) protein. The Spike $(\mathrm{S})$, membrane $(\mathrm{M})$, and envelope (E) proteins are enclosed in the lipid outer membrane of a virus particle. Corona's virus (means resembling a crown, as shown in fig. 1 [8]) is attributed because of protruding homotrimers of spike proteins from the lipid envelope.

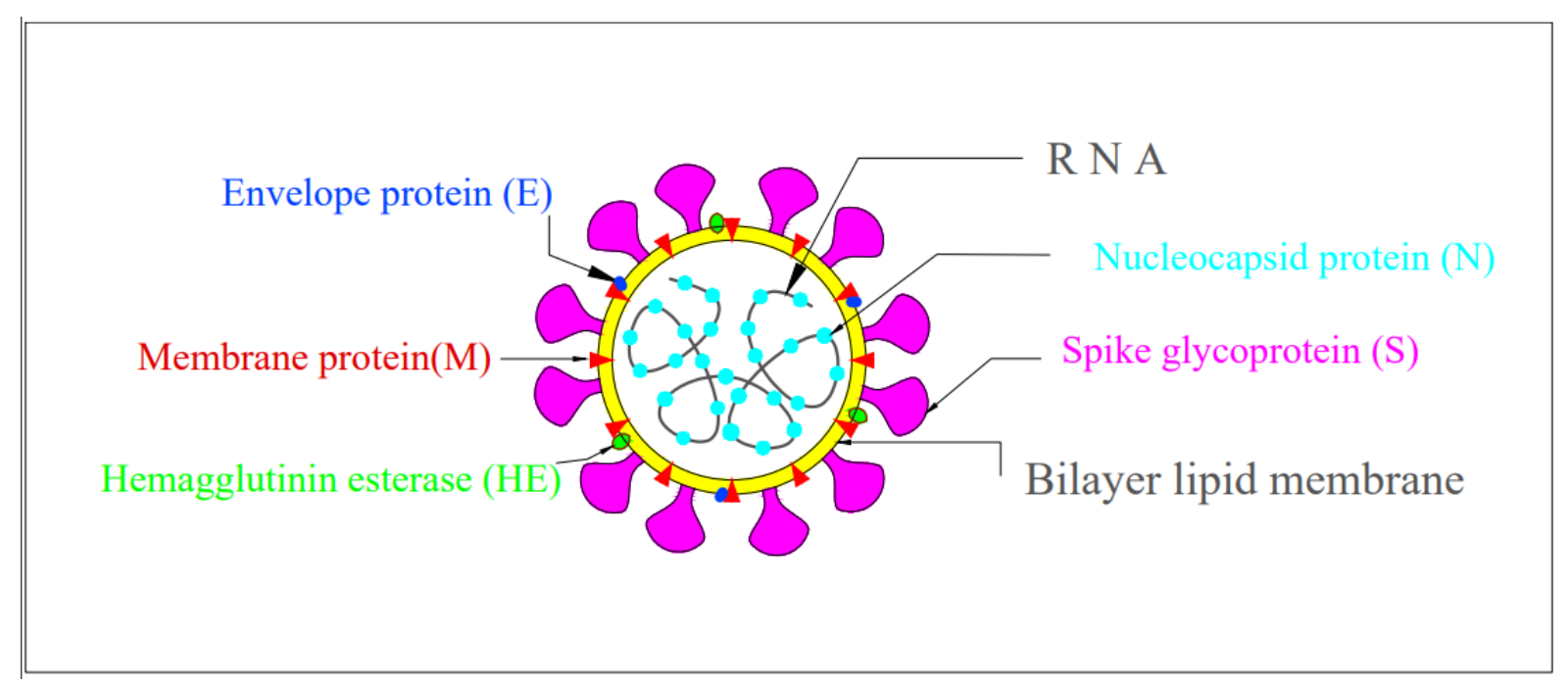

Figure 1. SARS-CoV-2 structure.

These spike proteins are involved in the entry of virus particles into the host cell through interactions with the Angiotensin-Converting Enzyme2 (ACE2) receptors of the host cell [9]. The S1 domain of S protein functions in recognition and binding to ACE2 receptors, followed 
by the fusion of the virus envelope with the host cell membrane through the interaction of the S2 domain. Unfortunately, most human organs express ACE2 receptors, but the lower respiratory system expresses them in high numbers [5]. The common symptoms after infection include fever, cough, fatigue, dyspnea, headache, and loss of taste or smell [10]. In severe cases, it is responsible for multi-organ failure or respiratory failure. The virus transmits via direct person-to-person contact. The microdroplets formed through sneezing and coughing may spread the virus through the air [11]. The virus can remain active on different surfaces for a variable number of hours. A healthy individual coming in contact with such surfaces is also prone to infection. The virus is isolated from fecal swabs, also increasing the chances of fecaloral transmission [5].

Recently, several research and review papers described the evolutionary reservoir, possible intermediate host [12], genomic source [6], and clinical characteristics of the virus SARS-CoV-2 [13]. A group of clinicians and scientists from the University of Hong Kong conducted a study in Shenzhen. It provided several important features of the disease. Their study gave the first concrete evidence for human-to-human transmission of SARS-CoV-2. An attack rate of $83 \%$ within the family context indicates the high transmissibility of SARS-CoV2 [11]. The study helped to direct the way for the control and management of COVID-19. Another group raised several important research questions that can help scientists to direct their research [14]. The group discussed the chances of SARS-CoV-2 becoming another community-acquired human Coronavirus just like the other four human Coronaviruses (229E, OC43, HKU1, and NL63) causing common cold only. The basic reproductive number (R0) of SARS-CoV-2 has been estimated to be 2.68 , resulting in an epidemic doubling time of about 6.4 days [15]. The R0 of SARS-CoV was found 2; however, R0 of SARS-CoV-2 could go approximately up to 4 . It is important to know the real $\mathrm{R} 0$ for the implementation of effective control measures [14]. It is difficult to identify the spread through presymptomatic virus shedding and patients with mild and unspecific symptoms $[11,16]$.

\subsection{Diagnosis.}

The present standard diagnostic method is through the real-time polymerase chain reaction (RT-PCR) technique [17]. However, this technique is costlier and takes time for results. Earlier, group testing was suggested to save time and cost where samples of a group are mixed. A small aliquot is subjected to testing for the detection of a pathogen. If the test is positive, then all the samples are retested individually [18].

Table 2. Diagnostic methods for the detection of SARS-CoV-2.

\begin{tabular}{|c|c|c|c|}
\hline $\begin{array}{l}\text { Diagnostic } \\
\text { Method }\end{array}$ & Sample & Detects & Confirmation of the test \\
\hline RT-PCR & Nasopharyngeal swab & Viral RNA & Active infection \\
\hline ELISA & Serum & IgG/IgM & $\begin{array}{l}\text { IgM- Present infection } \\
\text { IgG- Past infection }\end{array}$ \\
\hline ELISA & $\begin{array}{l}\text { Serum/Feces/Nasopharyn } \\
\text { geal swabs }\end{array}$ & Viral proteins & Active infection \\
\hline HRCT Scan & CT scan of lungs & CT score & Possible SARS-CoV-2 infection \\
\hline Biosensors & $\begin{array}{l}\text { Nasopharyneal swabs/ } \\
\text { Serum }\end{array}$ & $\begin{array}{l}\text { Viral RNA/Viral protein/ } \\
\text { Antibodies }\end{array}$ & $\begin{array}{l}\text { Active or past infection based on } \\
\text { analyte detected }\end{array}$ \\
\hline $\begin{array}{l}\text { NPs based } \\
\text { assay }\end{array}$ & $\begin{array}{l}\text { Nasopharyneal swabs/ } \\
\text { Serum }\end{array}$ & $\begin{array}{lcc}\text { Viral } & \text { RNA/ } & \text { Viral } \\
\text { protein/Antibodies } & \end{array}$ & $\begin{array}{l}\text { Active or past infection based on } \\
\text { analyte detected }\end{array}$ \\
\hline
\end{tabular}

There is a need for even faster and reliable techniques to isolate the suspected to prevent further spread of the disease. This will help eliminate people's unnecessary quarantine and 
prevent further increase in viral load and reduce complications. Immunological assays can serve the purpose. They work based on antigen/antibody interactions, whereas RT-PCR works based on viral RNA. IgM and IgG antibodies were detected after 3-6 and 8 days post SARS infection [19]. A review by Sheikhzadeh and co-workers describes in detail various diagnostic techniques for COVID-19 [20]. A few of the diagnostic techniques are summarized in table2.

\subsection{Therapeutic strategies.}

Until recently, there was no proven treatment or approved vaccine available to treat the disease [21]. Several labs across the globe are working on developing different therapeutic strategies like effective vaccines, neutralizing antibodies, and various antiviral agents. Trials using conventional inactivated vaccines are also under process. Other vaccine synthesis approaches like live attenuated vaccines, subunit vaccines, and vectored vaccines are also being tested. Table 3 enlists some vaccines approved and under development for the prevention of COVID-19. However, even if the vaccines are available, it has been suggested to follow preventive measures like physical distancing, use of masks at public places, repeatedly clean hands using soap, use sanitizer, isolate the infected person, and counsel.

Table 3. Various vaccines approved and underdeveloped against SARS-CoV-2.

\begin{tabular}{l|l|l|l} 
Developer & Candidate vaccine & Description & Status \\
\hline Pfizer, BioNTech & BNT162b2 & mRNA based vaccine & Approved \\
\hline Moderna & mRNA-1273 & mRNA based vaccine & Approved \\
\hline Sinovac Research & CoronaVac & Inactivated virus & Approved \\
\hline $\begin{array}{l}\text { Gamaleya } \\
\text { Institute, }\end{array}$ & Non-replicating viral vector & Approved \\
\hline $\begin{array}{l}\text { Wuhan Int. of biological } \\
\text { Products, Sinopharm }\end{array}$ & BBIBP-CorV & Inactivated virus & Approved \\
\hline $\begin{array}{l}\text { Federal Budgetary Research } \\
\text { Institution }\end{array}$ & EpiVacCorona & Peptide vaccine & Approved \\
\hline Novavax & NVX-CoV2373 & Nanoparticle vaccine & Phase 3 \\
\hline Bharat Biotech & Covaxin & Inactivated virus & Phase 3 \\
\hline Johnson \& Johnson & JNJ-78436735 & Non-replicating viral vector & Phase 3 \\
\hline Cansino Biologics & Ad5-nCoV & Recombinant vaccine & Phase 3 \\
\hline $\begin{array}{l}\text { AstraZeneca, } \\
\text { University of Oxford }\end{array}$ & AZD1222 & $\begin{array}{l}\text { Adenovirus } \\
\text { chimpanzee }\end{array}$ & Phase 3 \\
\hline Zydus Cadila & ZyCoV-D & DNA Vaccine & Phase 2
\end{tabular}

\subsection{The existing treatments.}

The possible drug for COVID-19 treatment includes remdesivir, an anti-Ebola drug that is a nucleotide analog. This drug prevented replication of MERS-Cov in monkeys [22]. The obtained results include reducing the severity of disease and virus replication. The reduced lung damage indicates it as a promising drug. Caly and co-workers found that Ivermectin, an antiparasitic FDA approved drug, can reduce viral RNA expression $~ 5000$ fold in just $48 \mathrm{~h}$ postinfection [23]. Other candidate drugs include viral replication inhibitors- favipiravir, azithromycin, chloroquine, hydroxychloroquine, ACE-2 blocker Arbidol, monoclonal antibodies Tocilizumab, Sarilumab, etc. [24]. However, they need to go through further clinical investigations [14]. Table 4 describes a few of the possible therapeutic agents against SARSCoV-2; however, better results can be achieved using certain combination therapies [25]. A French group tried to assess the effect of hydroxychloroquine in combination with azithromycin. It was found that this combination is more efficient in eliminating the virus than individual drugs [26]. Some combination therapies are under clinical trials where, along with antiviral agents, dietary supplements like zinc sulfate, vitamin C, and vitamin D3 can boost the 
immune response against the virus (https://clinicaltrials.gov/ct2/show/NCT04482686). In another study, a triple combination of interferon beta-1b, lopinavir-ritonavir, and ribavirin was tested on a limited population of COVID-19 infected patients. The findings proved that the triple combination is more effective than lopinavir-ritonavir alone [27].

Table 4. Possible therapeutic agents against SARS-CoV-2.

\begin{tabular}{|c|c|c|c|c|c|}
\hline Sr. No. & $\begin{array}{l}\text { Therapeutic } \\
\text { agent }\end{array}$ & Description & Mode of action & Current Use & Reference \\
\hline 1 & Chloroquine & Organic compound & $\begin{array}{l}\text { Works through endosomal } \\
\text { acidification, which prevents } \\
\text { virus binding and viral RNA } \\
\text { release into the cytoplasm }\end{array}$ & Antimalarial drug & {$[28]$} \\
\hline 2 & Remdesivir & Adenosine analog & $\begin{array}{l}\text { Inhibit viral replication via } \\
\text { inhibiting the RNA-dependant } \\
\text { RNA polymerase }(\mathrm{RdRp})\end{array}$ & $\begin{array}{l}\text { Ebola virus, } \\
\text { MERS-Cov }\end{array}$ & [17] \\
\hline 3 & Ivermectin & Macrocyclic lactone & Inhibit nuclear import of host & $\begin{array}{l}\text { Anti-parasitic } \\
\text { agent }\end{array}$ & {$[23]$} \\
\hline 4 & $\begin{array}{l}\text { Favipiravir and } \\
\text { Ribavirin }\end{array}$ & Guanine analogs & $\begin{array}{l}\text { Inhibit viral replication via } \\
\text { interfering with the cellular } \\
\text { nucleotide } \\
\text { synthesis }\end{array}$ & Hepatitis C Virus & {$[29,30]$} \\
\hline 5 & $\begin{array}{l}\text { Lopinavir and } \\
\text { Ritonavir }\end{array}$ & Protease inhibitors & $\begin{array}{l}\text { Inhibit viral replication } \\
\text { through binding to the viral } \\
\text { proteases responsible for } \\
\text { proteolytic cleavage }\end{array}$ & $\begin{array}{l}\text { Human } \\
\text { Immunodeficienc } \\
\text { y Virus }\end{array}$ & [31] \\
\hline 6 & Azithromycin & Antibiotic & $\begin{array}{l}\text { Prevents secondary bacterial } \\
\text { infections through inhibition of } \\
\text { protein synthesis }\end{array}$ & $\begin{array}{l}\text { Bacterial } \\
\text { infections }\end{array}$ & {$[32]$} \\
\hline 7 & Tocilizumab & Monoclonal antibody & Blocks I-6 mediated responses & $\begin{array}{l}\text { Rheumatoid } \\
\text { arthritis }\end{array}$ & [33] \\
\hline
\end{tabular}

However, all these therapeutic approaches are not always effective. Hence, there is a need for an alternative or complementary approach to finding an effective treatment.

\section{Photodynamic Therapy (PDT), the Possible Alternative}

Based on its non-invasive nature, photodynamic therapy (PDT) or photodynamic inactivation (PDI) overcomes traditional treatment methods like surgery, chemotherapy, and radiotherapy. Along with this, it has very few or negligible side effects and low systemic toxicity [28]. Some studies have reported that a PDI can inactivate all known microorganisms classes, like bacteria (Gram-positive and Gram-negative), fungi, protozoa, viruses, etc. [29$31]$.

\subsection{Mechanisms of photodynamic therapy.}

In PDI/PDT, a non-toxic compound called a PS is irradiated mostly with non-toxic visible light of suitable wavelength to match the PS absorption peak. The mechanism is diagrammatically explained in Figure 2 [32]. PDT works in three stages: excitation of PS, generation of ROS, and pathogen damage [33]. The reactions start when the light irradiated is absorbed by PS. It forms a short-lived first excited singlet state. Now, this exciting singlet PS forms a much longer-lived excited triplet state through the intersystem crossing. The survival duration of this excited triplet state is sufficient enough to carry out further chemical reactions. The available molecular oxygen and the triplet PS now react to produce type I and type II photochemical reactions leading to ROS formation [34]. 


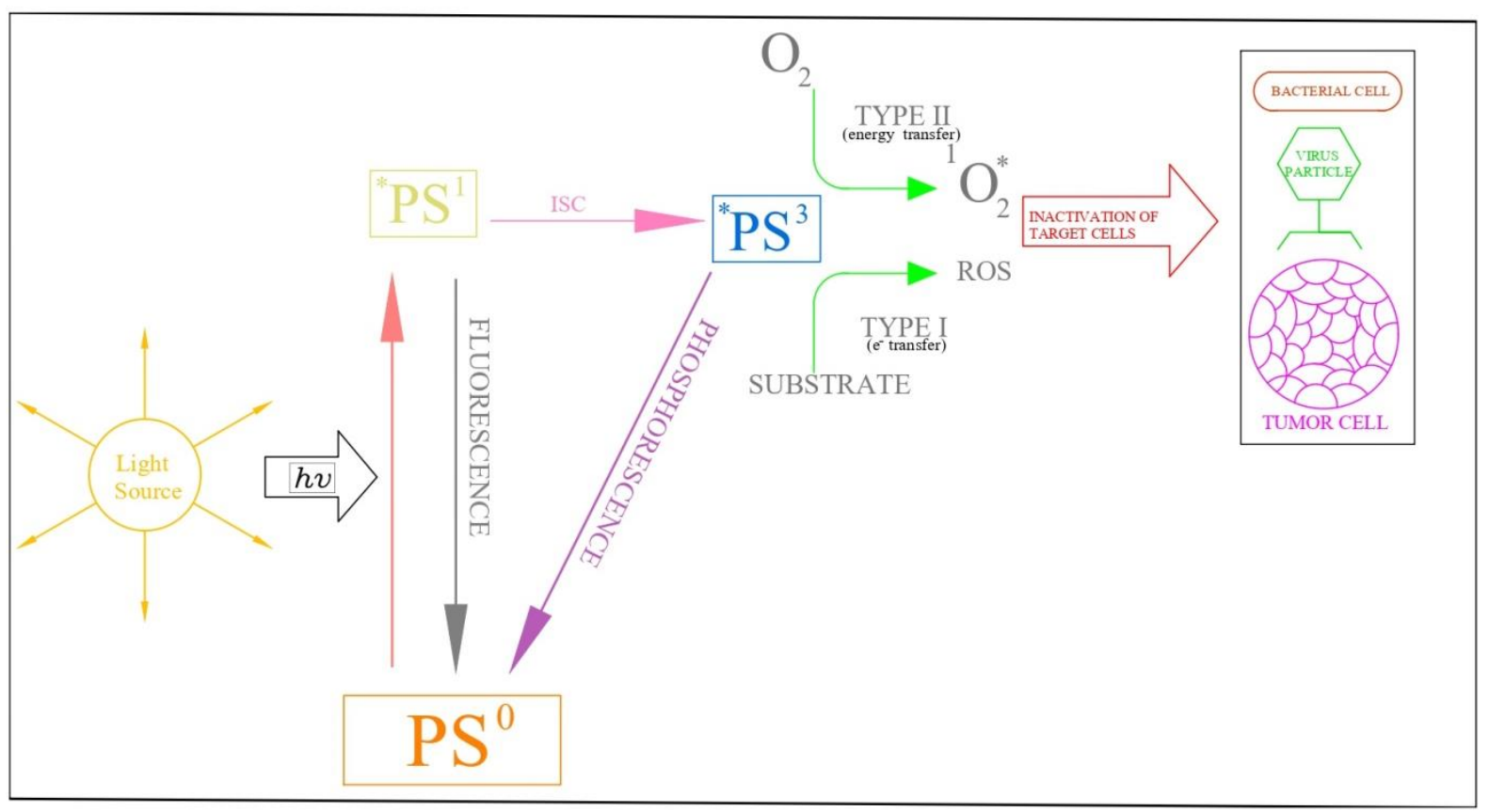

Figure 2. Schematic representation of Photodynamic inactivation: Ground state photosensitizer (0PS) absorbs light to form the first excited singlet state ( ${ }^{1} \mathrm{PS}$ ) that (in addition to losing energy by fluorescence or conversion to heat) undergoes intersystem crossing to form the long-lived first excited triplet state $\left({ }^{3} \mathrm{PS}\right)$. The triplet state can undergo type 1 (electron transfer) photochemical reaction to form superoxide and hydroxyl radical, and/or type 2 (energy transfer) photochemical reactions to form singlet oxygen. These ROS can damage and kill all known forms of microorganisms through oxidation.

It is seen from Figure 2 that, in type, I photochemical reactions, electron-transfer occurs between the excited state PS and available environmental oxygen in the system. It directly or indirectly leads to the production of ROS (e.g., superoxide $\left(\mathrm{O}^{\circ-}\right)$, hydrogen peroxide $\left(\mathrm{H}_{2} \mathrm{O}_{2}\right)$, hydroxyl radicals $\left(\mathrm{HO}^{\circ}\right)$ and hydroperoxyl radicals $\left(\mathrm{HOO}^{\circ}\right)$ that are harmful to cells. Type II photochemical reactions involve electron spin exchange in which triplet-triplet interactions are spin-allowed. The ground state oxygen $\left({ }^{3} \mathrm{O}_{2}\right)$ is already in the triplet state. Now, the excited triplet PS reacts with triplet oxygen leading to energy transfer through electron spin exchange. In this process, singlet oxygen $\left({ }^{1} \mathrm{O}_{2}\right)$ is produced. The ROS produced in both the type I and type II processes carry out cellular biomolecules' oxidation like lipids, proteins, and nucleic acids. In the case of microbial pathogens, the damage is caused at the cell wall of bacteria. Pathogen cellular structure gets destructed, which results in loss of selective permeability, leading to the release of intracellular material. In the case of viruses, the lipids and proteins of the capsid, as well as nucleic acids (RNA/DNA), can be targeted by formed ROS [32].

\subsection{Photosentizers (PSs).}

In PDT, targeted cells are locally killed by reactive oxygen species (ROS) such as ${ }^{1} \mathrm{O}_{2}$ produced by a photosensitizer (PS) under illumination in the presence of oxygen [35]. Different types of PS are being used, and each has its Pros and Cons. A PS producing a high ${ }^{1} \mathrm{O}_{2}$ quantum yield and excellent photostability and biocompatibility is preferable for effective PDT. To act as a PS, the compound should have the ability to generate ROS upon illumination. A wide group of chemical compounds starting from natural plant extracts to industrial dyes can act as PS. Compounds like fullerenes, carbon materials, metals, and their oxides, complex synthetic ${ }^{1} \mathrm{O}_{2}$ generating and delivering molecular systems, and products from the materials sciences can act as PS. Plant extract psoralen can show phototoxic effects independent of oxygen availability 
[36]. Organic PDT agents' drawbacks include poor water dispersibility, photostability, and their inability to be absorbed in the region $(470 \mathrm{~nm})$ where the skin is most transparent $[37,38]$. The best alternative to organic agents is semiconductor quantum dots (QDs). They are superior to organic photosensitizers in terms of photostability and water dispersibility [39, 40]. The disadvantage associated with them is their low ROS-generation efficiency and cytotoxicity during clinical trials [41, 42]. The demonstrated solution to overcome this limitation is modifying semiconductor QDs with a traditional PDT agent (porphyrin derivative, Ce6) and then coat them with a shell of peptides [43]. A Chinese group synthesized highly waterdispersible graphene QDs (GQDs) in large quantities using a hydrothermal method with polythiophene derivatives (PT2) as the carbon source [44]. Synthesized GQDs showed a broad absorption in the provided UV-visible region with a strong emission peak at $680 \mathrm{~nm}$. It was also reported that the synthesized GQDs exhibit good biocompatibility and excellent ${ }^{1} \mathrm{O}_{2}$ generation capability.

\subsection{PDT against SARS-CoV-2.}

PDT can be one of the complementary/alternative treatment approaches to target SARS-CoV-2. As shown in figure 3, ROS's major targets formed upon excitation of PS can target viral membrane, proteins, and RNA of SARS-CoV-19, leading to inactivation of the virus [45]. Various PSs have been tested against a range of viruses and are proved effective in controlling their growth. The PSs showing the inhibition process over a wide range is preferable.

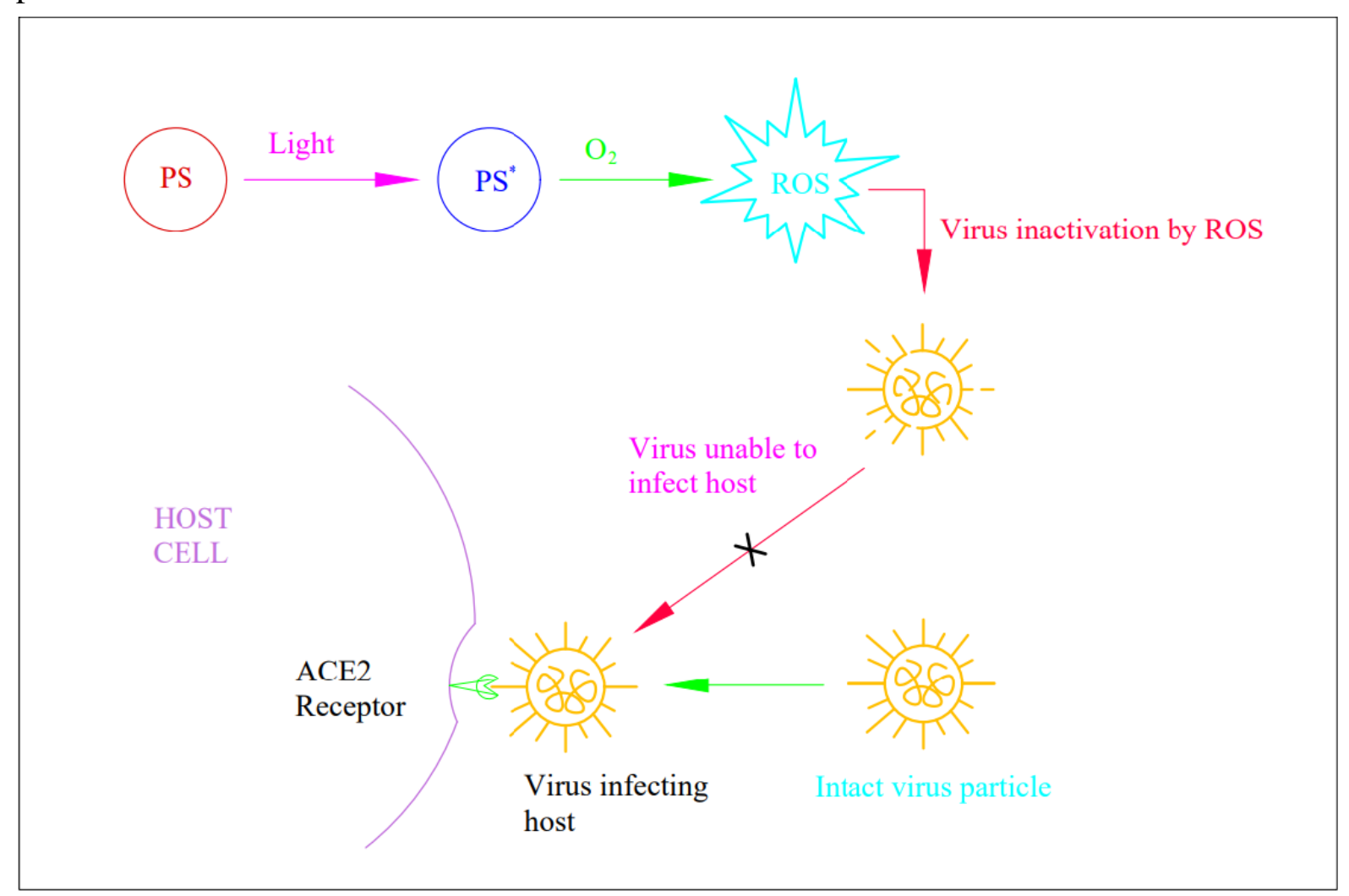

Figure 3. Virus inactivation by PDT and prevention of infection: The ROS formed by excited (PS*) using $\mathrm{O}_{2}$ targets viral membrane, proteins, and RNA, thereby inhibiting its binding with the host and ultimately the end of the virus life cycle.

Curcumin has been tested against feline coronavirus where a curcumin biconjugate synthesized by the reaction of curcumin with decanoyl chloride and palmitoyl chloride in 1:2 
molar proportion in the presence of 4-Dimethylaminopyridine (DMAP) in anhydrous pyridine showed inhibition (EC50 value $0.029 \mu \mathrm{M}$ ) of both feline corona and feline herpesviruses [46]. In order to prevent virus spread through platelet transfusion, Lin and co-workers successfully inactivated SARS-CoV using psoralen amotosalen- $\mathrm{HCl}$ in a platelet concentrate. The photochemical treatment involved $150 \mu \mathrm{M} / \mathrm{L}$ amotosalen with UVA light $\left(3 \mathrm{~J} / \mathrm{cm}^{2}\right)$ and achieved $>5.8$ log reduction in viral load [47].

When illuminated under UVA light, the psoralen compound 4'-aminomethyl-trioxsalen (AMT) inactivated the MERS-CoV [48]. In another study conducted to inactivate MERS-CoV from plasma, riboflavin was used. The riboflavin and UV light treatment reduced the virus titer below the detection limit. It can prevent transfusion of the virus through plasma products [49]. There is also a report of the use of photocatalytic titanium apatite filter (PTAF) filter for inactivation (described under titania photocatalysis section below) of SARS-CoV using UV and non-UV [50].

To improve the effectiveness of PDT against COVID-19, the correct amalgamation of recent technologies like nanotechnology can be more fruitful. The nanoparticles have been widely studied for their diverse uses in diagnosis and treatments against various microbes and diseases.

\section{Nanoparticles \& Nanomedicine in PDT}

The union of PDT with nanotechnology helped to enhance the effectiveness of photochemical treatment. This combination helped improve the light dose, and irradiance(the flux of radiant energy per unit area) required [51]. Kendall and Morton described PDT for skin disease treatment, where most of the damage by singlet oxygen occurs to the membranes around mitochondria and lysosomes. This releases destructive proteins from these cell organelles and causes further destruction through necrosis and apoptosis. During the treatment, the tumor cells are expected to accumulate more PS or its precursor because of their high metabolic rate. The light used is mostly red because of its deep penetration power. The total light dose and irradiance should be appropriately controlled to avoid undesirable heating of the skin. PDT has been successfully implemented experimentally to treat various skin diseases like squamous cell carcinoma (SCC), benign skin diseases like psoriasis, and viral warts using aminolevulinic acid (ALA) as a PS. The nanoparticles are used to improve the binding and uptake of PS by the microbial cells and improve photoinactivation kinetics [52]. Rose Bengal is one of the most frequently used PS due to its ready availability, high water solubility, high singlet oxygen quantum yield, and low photodegradation rate [53]. It has been tried with silica nanoparticles to inactivate Gram-positive bacteria like methicillin-resistant Staphylococcus aureus (MRSA) [54].

\subsection{Titania photocatalysis.}

The acceleration of a light-mediated reaction in the presence of a catalyst is called photocatalysis [55]. Because of its highly efficient photocatalytic properties, which allow the killing of pathogenic microbes, titanium dioxide $\left(\mathrm{TiO}_{2}\right)$ is increasingly used as a photocatalyst [56]. The advantage of photocatalysis is that sunlight or UV radiation is used to trigger the disinfection process using a catalyst $\left(\mathrm{TiO}_{2}\right)$. The electron-hole pair generated after the light absorption reacts with surrounding water molecules and subsequently produces reactive 
hydroxyl radicals. These hydroxyl radicals $(\bullet \mathrm{OH})$ are potent to kill almost all microbes, including viruses [57]. Some reports of virus inactivation using $\mathrm{TiO}_{2}$ are enlisted in Table 5.

Table 5. Viruses are shown to be inactivated by $\mathrm{TiO}_{2}$ photocatalytic inactivation.

\begin{tabular}{l|l|l|l} 
Host & Virus & Light used & Reference \\
\hline Human & $\begin{array}{l}\text { Hepatitis B virus surface antigen } \\
\text { HBsAg }\end{array}$ & $\begin{array}{l}\text { Merecury lamp }(0.6 \mathrm{~mW} / \mathrm{cm} 2) \text { at 365 } \mathrm{nm} \\
\text { wavelength or sunlight }\end{array}$ & {$[64]$} \\
\hline Human & Influenza A/H1N1 & UV light at 365nm & {$[65]$} \\
\hline Human & Influenza A/H3N2 & UV irradiation & {$[66]$} \\
\hline Human & $\begin{array}{l}\text { Poliovirus type 1 (ATCC VFR- } \\
192)\end{array}$ & Fluorescent light and sunlight & {$[67]$} \\
\hline Human & SARS coronavirus & UV and non-UV irradiation & {$[56]$} \\
\hline Birds & Influenza (avian) A/H5N2 & UV light & {$[68]$}
\end{tabular}

The HBsAg antigen of the human hepatitis $\mathrm{B}$ virus was inactivated using $\mathrm{TiO}_{2}$ under the irradiation of mercury lamp and sunlight separately [58]. Han and co-workers used a photocatalytic titanium apatite filter (PTAF) for the inactivation of SARS-Cov. Under non-UV irradiation, the PTAF filter inactivated $99.99 \%$ SARS-Cov in $6 \mathrm{~h}$ time duration, while it was completely inactivated when irradiated with UV light [50].

\subsection{Carbon quantum dots and nanotubes.}

Quantum dots are nanostructures having several applications in optics and biomedical technologies. As shown in figure 4, carbon dots can prevent various virus particles' entry inside the host cells [59-62].

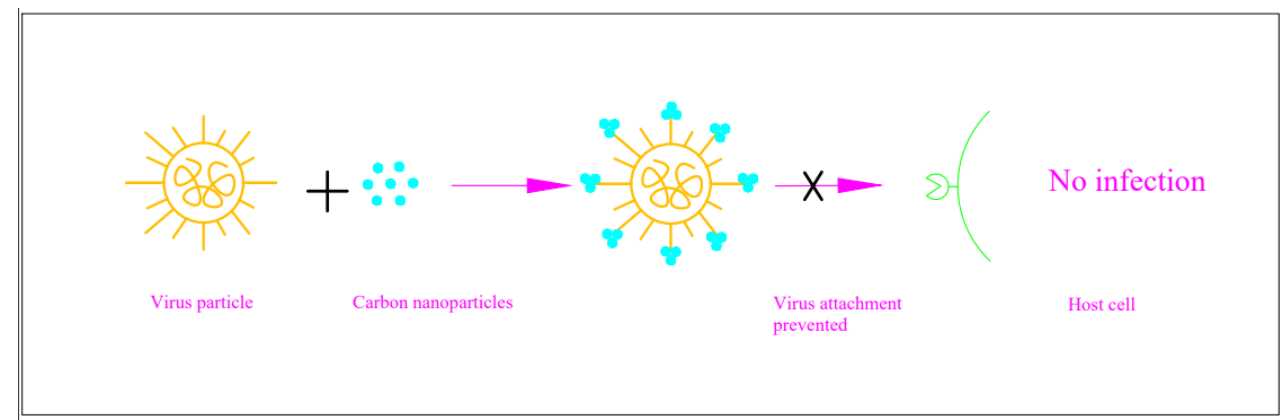

Figure 4. Carbon nanoparticles preventing viral attachment with the host: Carbon nanoparticles can mask or modify the virus's spike protein. This prevents the virus's binding to the host receptor and furthers the virus life cycle process.

Łoczechin and co-workers investigated the potential of seven different functional carbon quantum dots (CQDs) against HCoV-229E coronavirus [63]. In their studies, to derive first-generation antiviral CQDs, the group used hydrothermal carbonization of ethylenediamine/citric acid as carbon precursors and then modified with boronic acid ligands. The second-generation CQDs were derived using 4-aminophenylboronic acid with no further modifications. However, the $\mathrm{EC}_{50}$ value for the first and second-generation CQDs was significantly different. It was found to be $52 \pm 8 \mu \mathrm{g} \mathrm{mL}^{-1}$ and $5.2 \pm 0.7 \mu \mathrm{g} \mathrm{mL}{ }^{-1}$, respectively. The interactions of CQDs functional groups with $\mathrm{S}$ receptor of the virus prevented virus particles' entry inside the host cells. The CQDs also showed inhibition of viral genome replication.

In addition to CQDs, multi-walled carbon nanotubes (MWCNTs) have also been reported as potent antiviral agents. Visible light-induced excitation of Porphyrin-conjugated MWCNTs significantly inactivated the influenza A virus's ability to infect mammalian cells. This report inspired others to the development of MWCNTs for antiviral therapeutics [64]. In 
another report, MWCNT arrays were used to remove enterohemorrhagic E. coli O157:H7 (EHEC) using $\mathrm{TiO}_{2}$ nanoparticles [65].

\subsection{Graphene.}

Graphene and graphene oxide sheets have also been reported as antimicrobial agents. Two different groups used them for solubilization of hydrophobic PS hypocrellin A [66] and methylene blue [67] independently. In another report, electrochemically produced GQD used to kill two bacteria, MRSA and E. coli. These researchers used a green laser (470 nm, $1 \mathrm{~W}$ ) for photoactivation. This generated the ROS, which selectively killed only bacteria and not mouse spleen cells [68]. Song and his group reported the use of graphene oxide (GO) for the killing of two viruses EV71 (pathogenic agents of hand, foot, and mouth disease) and H9N2 (endemic gastrointestinal avian influenza A virus of waterfowl) [69].

\subsection{Gold $(A u) \&$ silver $(A g)$ nanoparticles.}

$\mathrm{Au}$ and $\mathrm{Ag}$ nanoparticles are widely used in drug delivery systems. Both of them showed anti-HIV activity [70, 71]. Gianvincenzo and co-workers (2010) used Au NPs to prevent HIV infection of T-cells in vitro. The Au NPs coated with multiple copies of an amphiphilic sulfate-ended ligand bind with the glycoprotein gp120 of HIV envelope, thereby affecting the adsorption/fusion process virus. Ag NPs capped with mercaptoethane sulfonate (Ag-MES) showed inhibition of Herpes Simplex virus type-1 (HSV-1). The HSV-1 virus attachment and entry into cells involve interaction between glycoprotein of the viral envelope and cell surface heparin sulfate. Ag-MES NPs block the virus entry into cells through a competition to bind with cellular heparin sulfate through their sulfonate end groups, subsequently preventing the infection [72]. Ag NPs also showed replication inhibition in Hepatitis $\mathrm{B}$ and respiratory syncytial viruses $[73,74]$. They used $\mathrm{TiO}_{2} / \mathrm{Ag}$ mixture for surface sanitization of buildings in Milan and found it effective against the virus [75].

\subsection{Up conversion nanoparticles (UCN).}

The best example of upconversion is a conversion of infrared light to visible light. So the upconversion is anti-Stokes type emission and can be defined as successive absorption of two or more photons leading to the emission of light at a shorter wavelength than the excitation wavelength [76]. Most of the powerful PS are optimally excited with UV or short-wavelength (blue) visible light. However, these wavelengths possess inadequate tissue penetration ability $[33,77]$. Rare earth metal salts with their controlled properties like solubility, particle size, crystallographic phase, optical properties, and shape can be used for producing highly efficient UC nanocrystals. Best and efficient upconversion can be done when solid-state lanthanide ions are used to dye nanocrystals [78]. Lim and co-workers synthesized near-infrared-to-visible UC nanoparticles consisting of sodium yttrium fluoride (NaYF4) nanocrystals co-doped with ytterbium $(\mathrm{Yb} 3+)$ and erbium $\left(\mathrm{Er}^{3+}\right)$ ions. The UCNs were coated with polyethyleneimine (PEI), and to these UCNs surface, the PS zinc phthalocyanine ( $\mathrm{ZnPc}$ ) was attached. The UCN was converted to a nanotransducer by irradiating it with NIR of $980 \mathrm{~nm}$, which resulted in visible light formation. This visible-light excited the PS ZnPC and produced ${ }^{1} \mathrm{O}_{2}$. The produced ROS reduced dengue virus serotype 2 (DENV2) and adenovirus type 5 (Ad5V) titers. The same group conducted an animal trial where they inoculated light-treated DENV2 virus suspension into mice and found no disease [33]. 


\section{Advantages of PDT/PDI}

Light can be used as an activator of drugs (pro-drug to drug conversions) in photomedicine [45]. Avery common example is the treatment of malignant cells and tissue through the generation of light-induced ROS (PDT) and the inactivation of microbes (PDI) [79]. The killing of microbes through PDT is sometimes referred to as PACT (photodynamic antimicrobial chemotherapy) [80]. The light-induced formation of radicals, anions, and in general, ROS (via Type I and Type II mechanisms) damages the target cells. It does not involve any specific interaction with any of the cellular receptors. Instead, it targets biomolecules of the cell wall or membrane structures or the lipids, proteins, and nucleic acids of microbes. Niels Ryberg Finsen was awarded 1903 Nobel prize in medicine for light-mediated treatment of lupus vulgaris, a form of tuberculosis that attacks the skin, especially the face and neck. Finsen initially used filtered sunlight for the treatment. Later, the Finsen lamp was widely used to produce UV light to treat the lupus vulgaris [81]. This light-induced treatment does not lead to the development of resistance, which happens in the case of drugs like antibiotics [82]. However, photodynamic treatment triggers an interesting immune response, making it a more interesting complementary treatment option [83]. Amongst several PSs approved for PDT, most of them are used in cancer treatment [84]. Based on some reports of cancer induction on exposure to virus infection, it is also possible that some PDI components may have antiviral properties [85]. In certain cases, photo inactivated viruses can still trigger immune response more strongly like a vaccine $[48,86]$. Generally, viruses may be composed of proteins, lipids, and single/ double-stranded DNA/RNA. Nucleic acids form the core, while protein forms the outer cover and, in some cases, lipids. These viral structures are the three main molecular targets for the PDI and the produced ROS in the process [87, 88]. Nucleic acids and proteins are always found in viruses, but if lipids are also found, the virus becomes more sensitive to PDI $[89,90]$.

The PS can target viral nucleic acids (DNA and RNA) by directly intercalating with them. Because of its positive charge, methylene blue can cross the viral envelop and intercalate with their negatively charged nucleic acids (DNA/RNA) [91, 92]. Degar et al. [103] suggested that electrostatic interactions are supposed to allow direct PS-DNA/RNA interactions (Table $6)$.

Table 6. Action of PS acting on nucleic acids of viruses.

\begin{tabular}{l|l|l}
$\begin{array}{l}\text { Photochemical } \\
\text { Reaction Type }\end{array}$ & Reaction Occurring & Impact of the Reaction \\
\hline Type I & $\begin{array}{l}\text { Addition of } \mathrm{O}_{2} \text { to short-lived carbon-centered } \\
\text { radicals, which originate from transformations of } \\
\text { the primarily formed radical cations }\end{array}$ & $\begin{array}{l}\text { Oxidative transformations destroy the } \\
\text { DNA leading to fragmentation, single- } \\
\text { strand breaks, and cross-linking with } \\
\text { proteins. }\end{array}$ \\
\hline Type II & $\begin{array}{l}{[4+2]-,[2+2]-\text { cycloadditions, and 'ene' reactions }} \\
\text { with }{ }^{1} \mathrm{O}_{2} \text { dominate }\end{array}$ &
\end{tabular}

The PS can also act on viral proteins and lipids. The PS, like 5-amino levulinic acid (ALA), protoporphyrin IX (PpIX), hematoporphyrin derivatives (HpD), etc., have a high affinity to proteins and lipids. They target the outer structures like unsaturated lipids as well as envelope proteins [93-95]. Structural modifications like cross-linking of viral proteins are typically induced. The sites for photo-oxidative damage are frequently found at oxidationsensitive amino acids such as tryptophan, methionine, cysteine, histidine, and tyrosine. Additionally, protein folding of viral proteins may occur if there is a direct interaction between PS and virus proteins leading to termination of virus function [88]. 
COVID-19 has spread very rapidly and halted the entire world. Till today no promising vaccine has been found showing positive treatment against the virus. Various strains of COVID-19 have been found across the globe due to continuous mutations that occurred in COVID-19. So, finding a unique vaccine for all types of strains is a difficult task. The same case may be applied to other drugs. Talking about PDT does not act at a specific target. The virus comprises ssRNA and capsid proteins. Several researchers showed that PDT could be used to inactivate many types of viruses, as shown in Table 7.

Table 7. Photodynamic inactivation of various viruses.

\begin{tabular}{l|l|l} 
PS & Virus target & Reference \\
\hline Curcumin & HPV & {$[112]$} \\
& MNV-1 & {$[113]$} \\
\hline Perylenequinone- Hypericin & EIAV & {$[110]$} \\
\hline Graphene oxide & MS2 phage & {$[114]$} \\
\hline Porphyrins & T4 like sewage phage & {$[115]$} \\
\hline Chlorinphotoditazine & HSV, & {$[116]$} \\
& HPV & {$[117]$} \\
\hline Phthalocyanines & HIV & {$[118]$} \\
\hline Riboflavin & MERS & {$[55]$} \\
\hline Psoralen Amotosalen & SARS Corona virus, & {$[106]$} \\
& Zika Virus, & {$[119]$} \\
\hline Phenothiazine methylene blue & Sindbis virus and HCV & {$[120]$}
\end{tabular}

Few reports showed inactivation of earlier forms of coronavirus using PDT [49, 96]. In their work for the inactivation of SARS-Cov in blood, Pinna and co-workers successfully used amotosalen. This activity of amotosalen can be used in the INTERCEPT blood system to stop the spread of many viruses, including SARS-Cov, through blood components like platelets [96]. The report of inactivation of MERS using riboflavin inspires the thought of PDT as an alternative for controlling the spread of COVID-19 [49]. Additionally, the released inactivated virus components may act to boost the immune system acting like a vaccine. Many plant metabolites have been used as PS for the treatment of viral infections. The Hypericin natural polycyclic quinine can be extracted from the Hypericum perforatum and used as a photosensitizer in photodynamic therapy against human immunodeficiency, hepatitis B and C virus, and many other viruses [97-99]. The hypericin requires molecular oxygen to generate the singlet oxygen species, which is needed for its potent antiviral activity in in-vitro and invivo [100, 101].

The light-dependent and light-independent antiviral hypericin activities showed dosedependent inhibition of HIV-expression under ambient light conditions [102]. The hypericin was found to induce the photochemical alterations in major capsid protein p24 of HIV, crosslinking of envelope $\mathrm{G}$ and M proteins of Vesicular stomatitis virus (VSV), Influenza virus, and Sendai virus led to impair the capacity of the virus to adhere/penetrate the host cells and consequently lose the infectivity and fusion function [88, 103, 104]. The antiviral action of hypericin was proposed to be associated with the inhibition of protein kinases activity, which is required to replicate several viruses and produce structural changes in gag - precursor protein [105]. The brominated hypericin derivatives show an increased quantum yield of singlet oxygen formation and exhibit potent antiviral activity against herpes simplex and influenza viruses [106]. Further, the hypericin loaded graphene oxide showed antiviral activity against the novel duck reovirus [107]. The hypericin mediated PDT was highly effective against the Adult-T cell Leukemia by induction of apoptosis and the suppression of viral transcription [108]. This study anticipated that hypericin is a promising drug for light-dependent antiviral activity in adult T cell leukemia (ATL)-targeted therapy. The hypericin has also been tested for 
its potential antiviral activity toward the coronavirus (Avian infectious bronchitis virus) in chickens $[109,110]$.

\section{Computational Approach.}

Computational chemistry/biology has become one of the essential approaches in modern drug discovery. It can significantly minimize the cost and time involved in the drug discovery process by developing new lead molecules or drug repurposing. It accelerates drug development by allowing scientists to narrow down the biological and synthetic testing efforts. Moreover, protein modeling, virtual screening, molecular docking, molecular dynamics, quantitative structure-activity relationship (QSAR), and absorption, distribution, metabolism, excretion, and toxicity (ADMET) tools have become the key parts of the computer-aided drug discovery process because of their reliable predictions [111]. The computational chemistry approach, such as molecular orbital calculations, has been used to design the photosensitizers in PDT by predicting the photochemical reactivity of PS and anticipating the mechanism of the chemopreventive effect on phototoxicity $[112,113]$. The quantum chemical calculations showed that the brominated hypericin has a high ROS formation ability compared to unsubstituted hypericin [114]. Further, the lipid membrane permeability of hypericin and its brominated derivatives have been tested in the presence of cholesterol by performing molecular dynamics simulation studies $[115,116]$. Furthermore, due to the importance of human serum albumin (HSA) in the storage and distribution of hypericin, its specific interactions with HSA may play a role in hypericin antiviral activity. Therefore, molecular docking and MD simulation studies have been performed on hypericin with HSA, bovine serum albumin (BSA), and rat serum albumin (RSA) [101, 117]. The molecular modeling and MD simulation have been performed in water/DMSO solvent to elucidate the hypericin- $\beta$-lactoglobulin complexes' photo functional properties to confer water solubility bioavailability, and biocompatibility of the hypericin [118]. The molecular docking studies of 40 antiviral phytochemicals against the main protease of SARS-CoV-2 showed the highest binding affinity $(-10.70 \mathrm{kcal} / \mathrm{mol})$ for hypericin pseudohypericin toward the main protease [119]. The hypericin forms four hydrogen bonds and five hydrophobic interactions, including one pi-alkyl interaction with catalytic Cys145 residue of the main protease of SARS-CoV-2 [119]. A simulation study supported this result, wherein RMSF data showed that binding of hypericin makes the main protease more flexible by inducing the local flexibility at Met49 (S2 pocket), Asn51, Pro52, Tyr154, Asp248, Arg279, and Phe294 residues [119]. Similar interactions were observed in another molecular docking study of hypericin with the main protease of COVID-19 [120]. Additionally, the homology modeling, MD simulation, and small-molecule docking studies were carried out for drug repurposing against the SARS-CoV-2 using viral Spike protein and Viral-Spike protein human ACE2 interface region as targets for docking studies [121]. In this study, the hypericin is obtained as one of the top-scoring ligands having the highest binding affinity toward the Spike protein of SARS-CoV-2 [121]. Therefore, keeping all the above facts in mind, the hypericin can act as a good photosensitizer in PDT to treat SARS-CoV-2.

\subsection{Futuristic computational biology approach for designing PS.}

The computational biology approach may pave the way to design a good photosensitizer in PDT to treat SARS-CoV-2 by performing the virtual screening of thousands of compounds in parallel using a human photosensitizer (PIH) dataset and phototoxicity in- 
vitro data (PIV) of photosensitizers. The photo safety or phototoxic potential of PS will be carried out using computational approaches such as ADMET prediction tools and predictive multitask deep neural network model $[122,123]$. The chemoinformatics approach will help predict the informative properties, including molecular weight distribution, non-carbon heavy atom numbers, lipophilicity, number of aromatics rings, and number of pi-bonds present in photosensitizers. The Bayesian statistics approach has been used to identify phototoxicity's structural pattern for photo-toxophore using the PIH dataset [124]. The quantum chemical $a b$ initio Density Functional Theory (DFT) calculations will be performed to predict and quantify accurate UV absorption of molecules and ground-state electronic properties [125]. The excitedstate properties of PS will be predicted using time-dependent DFT (TDDFT) theory using B3LYP functional and 6-31+G* [126].

Additionally, the computed HOMO and LUMO gaps (HLG) will help predict the phototoxicity window for PS $[127,128]$. The PS having the HLG range within the window of 6.50 to $8.60 \mathrm{eV}(\sim 140 \mathrm{~nm}-190 \mathrm{~nm})$ will be considered potentially phototoxic. Also, the machine learning methods (Random Decision Forests (RDF) and Deep Neural Networks (DNN) may offer rationalization and prediction of phototoxicity of PS from PIV and PIH datasets by generating an appropriate precision model, which will be a valuable strategy to reduce experimental testing [129]. Moreover, the quantitative determination of UV extinction coefficients of positively triggered compounds or PS obtained after the virtual screening of PIH and PIV datasets will be tested at a suitable wavelength. Finally, the in-vitro assays for photo safety of PS will be performed using 3T3 neutral red uptake assay (3T3 NRU), erythrocyte based photohemolysis assays, ROS assay and photochemical degradation of compounds using 'suntest' by commercial sun simulator [130-133]. In this way, the computational approach will guide the rational drug design of PS before chemical synthesis. Briefly, starting with in-silico predictions, followed by the determination of UV/VIS absorbance and the in-vitro 3T3 NRU test to identify nonphototoxic drugs, will help design the novel PS in PDT for treatment of SARS-CoV-2 infected patients. This will need to find appropriate photosensitizers that can inactivate SARS-CoV-2. Based on these several reports for the inactivation of various viruses through PDT, the chances of combating SARS-CoV-2 cannot be neglected. This kind of alternate strategy may help control the disease and save lives until a suitable vaccine or drug is available.

\section{Challenges and Future Applications}

As discussed earlier, when photo inactivated viruses act like a vaccine, they can boost the immune response more strongly. Here, the reverse should also be considered a side effect where inactivated viruses may reactivate and increase virus load [134]. The reversal of SARSCoV-2 under asymptomatic conditions can spread the disease in healthy individuals also. Another problem raised is based on the report in which treatment of cells with PS has shown internalization and infection of adenoviruses via a photochemical internalization mechanism. In this study, colorectal carcinoma cell lines were pre-incubated with the photosensitizer tetraphenyl porphyrin disulphonate (TPPS2a) or methylene blue derivates (MBD) followed by infection with adenovirus and light exposure. Then Fluorescent in situ hybridization (FISH) and RT-PCR techniques were used to quantify viral DNA in cellular nuclei. It was observed that more viral gene expression was associated with increasing light exposure and the cellular localization of PS. It was associated with endosomal rupture, which facilitated the virus's entry 
into the nucleus [135]. So, it necessitates the importance of killing all forms of pathogen. Literature explaining ROS's effect on nucleic acids and proteins in PDI is available extensively $[88,94,136]$. Both types I and II mechanisms can be active simultaneously, but the relative importance depends on the PS concentration, structure, and available oxygen [137-139]. Costa et al. experimentally proved that ${ }^{1} \mathrm{O}_{2}$ is most relevant compared to radical species, which plays a secondary role in the case of mammalian viruses [88].

A sufficient oxygen concentration should necessarily be present at the reaction site for effective ${ }^{1} \mathrm{O}_{2}$ generation [140]. This is important for both Type I vs. Type II photoreactions [88] to enhance PDT efficacy [141]. Nowadays, progress in vivo measurement of ${ }^{1} \mathrm{O}_{2}$ in living cells and tissue has also helped to optimize the illumination conditions for PDT through oxygen monitoring within target tissue [142]. The amount of oxygen consumption is directly related to the dose and source of light. To exert significant impact, localization of PS at the sensitive target site is also important as the decay of ${ }^{1} \mathrm{O}_{2}$ is very short in a biological environment and ends hardly on $\mu$ s time scale [143]. The localization of the PS decides its specific decay time. e.g., it is found to be $0.4 \pm 0.2 \mu \mathrm{s}$ in the vicinity of membranes in living cells [144] or $1.2 \pm 0.3$ $\mu$ s in blood vessels [140], but much longer times have also been found [145].

\section{Conclusions}

The therapeutic significance of PDT/PDA process is known for more than 100 years. It has been used for the treatment of cancer cells, inactivation of pathogens, including viruses. Despite this, PDT/PDA process is gaining popularity just recently. Amidst the search for alternative therapeutic approaches for the effective management of COVID-19, an attempt has been made to introduce the possibility of exploring PDT/PDA as an alternative or complementary treatment for COVID-19. Linking to current COVID-19 state of the art knowledge, a clear outline of the PDT/PDA process and the underlying mechanism has been described here. The PS and light play an important role in this process. With the advances in technology, various nanoparticles can also be used for increasing the therapeutic efficacy of the PDT/PDA treatment. This review offers an updated discourse on various PSs and nanoparticles used in PDT/PDA process along with mechanisms underlying PDT/PDA mediated inactivation of tumor cells/pathogens/viruses. An Intervention of a variety of PSs possessing different structures and functional properties has made PDT/PDA process broadly applicable, but at the same time, the technique is also compounded by challenges. The computational modeling, and various tools used in computational chemistry, such as protein modeling, virtual screening, molecular docking, etc., can be employed to implement this technique. This will also help to design the PSs in PDT/PDA by predicting the photochemical reactivity of PSs and anticipating the mechanism of the chemopreventive effect on phototoxicity. The literature on modeling and inactivating various viruses using PSs described here may reduce the cost and time involved in selecting or developing ideal PSs. Finally, we have discussed the advantages and limitations of the proposed therapy. Although there are significant challenges in the implementation of PDT/PDA, it has the potential to be employed in the management of COVID-19.

\section{Funding}

This research received no external funding. 


\section{Acknowledgments}

Mr. Sunil Bhapkar acknowledges the Council of Scientific \& Industrial Research for the research fellowship. Navanath Kumbhar sincerely acknowledges Savitribai Phule Pune University (SPPU) (Formerly Pune University), Pune, for providing the SPPU post-doctoral fellowship (ST/BL/2018-2018/0203).

\section{Conflicts of Interest}

The authors declare no conflict of interest.

\section{References}

1. He, F.; Deng, Y.; Li, W. Coronavirus disease 2019: What we know? Journal of Medical Virology 2020, 92, 719-725, https://dx.doi.org/10.1002/jmv.25766.

2. Zhou, P.; Yang, X.L.; Wang X.G.; Hu, B.; Zhang, L.; Zhang, W.; Si, H.R.; Li; Zhu, Y.; Li, B.; Huang, C.L.; Chen, H.D.; Chen, J.; Luo, Y.; Guo, H.; Jiang, R.D.; Liu, M.Q.; Chen, Y.; Shen, X.R.; Wang, X.; Zheng X.H.; Zhao, K.; Chen, Q.J.; Deng, F.; Liu, L.L.; Yan, B.; Zhan, F.X.; Wang, Y.Y.; Xiao, G.F.; Shi, Z.L. A pneumonia outbreak associated with a new coronavirus of probable bat origin. Nature 2020, 579, 270-273, https://doi.org/10.1038/s41586-020-2012-7.

3. Liu, Y.C.; Kuo, R.L.; Shih, S.R. COVID-19: The first documented coronavirus pandemic in history. Biomedical Journal 2020, 43, 328-333, https://doi.org/10.1016/j.bj.2020.04.007.

4. Sohrabi, C.; Alsafi, Z.; O’Neill, N.; Khan, M.; Kerwan, A.; Al-Jabir, A.; Iosifidis, C.; Agha, R. World Health Organization declares global emergency: A review of the 2019 novel coronavirus (COVID-19). International Journal of Surgery 2020, 76, 71-76, https://doi.org/10.1016/j.ijsu.2020.02.034.

5. Abd Ellah, N.H.; Gad, S.F.; Muhammad, K.; Batiha; G.E.; Hetta, H.F. Nanomedicine as a promising approach for diagnosis, treatment and prophylaxis against COVID-19. Nanomedicine 2020, 15, 2085-2102, https://doi.org/10.2217/nnm-2020-0247.

6. Lu, R.; Zhao, X.; Li, J.; Niu, P.; Yang, B.; Wu, H.; Wang, W.; Song, H.; Huang, B.; Zhu, N.; Bi, Y.; Ma, X.; Zhan, F.; Wang, L.; Hu, T.; Zhou, H.; Hu, Z.; Zhou, W.; Zhao, L.; Chen, J.; Meng, Y.; Wang, J.; Lin, Y.; Yuan, J.; Xie, Z.; Ma, J.; Liu, W.J.; Wang, D.; Xu, W.; Holmes, E.C.; Gao, G.F.; Wu, G.; Chen, W.; Shi, W.; Tan, W. Genomic characterisation and epidemiology of 2019 novel coronavirus: implications for virus origins and receptor binding. Lancet 2020, 395, 565-574, https://doi.org/10.1016/S0140-6736(20)30251-8.

7. Mousavizadeh, L.; Ghasemi, S. Genotype and phenotype of COVID-19: Their roles in pathogenesis. Journal of Microbiology, Immunology and Infection 2020, 1-5, https://dx.doi.org/10.1016\%2Fj.jmii.2020.03.022.

8. Cascella, M.; Rajnik, M.; Cuomo, A.; Dulebohn, S.C.; Napoli R.D. Features, Evaluation, and Treatment of Coronavirus (COVID-19). In: StatPearls [Internet]. Treasure Island (FL): StatPearls Publishing; 2020.

9. Seah, I.; Agrawal, R. Can the Coronavirus Disease 2019 (COVID-19) Affect the Eyes? A Review of Coronaviruses and Ocular Implications in Humans and Animals. Ocular Immunology and Inflammation 2020, 28, 391-395, https://dx.doi.org/10.1080\%2F09273948.2020.1738501.

10. Ai, T.; Yang, Z.; Hou, H.; Zhan, C.; Chen, C.; Lv, W.; Tao, Q.; Sun, Z.; Xia, L. Correlation of Chest CT and RT-PCR Testing for Coronavirus Disease 2019 (COVID-19) in China: A Report of 1014 Cases. Radiology 2020, 296, E32-E40, https://doi.org/10.1148/radiol.2020200642.

11. Chan, J.F.W.; Yuan, S.; Kok, K.H.; To, K.K.W.; Chu, H.; Yang, J.; Xing, F.; Liu, J.; Yip, C.C.Y.; Poon, R.W.S.; Tsoi, H.W.; Lo, S.K.F.; Chan, K.H.; Poon, V.K.M.; Chan, W.M.; Ip, J.D.; Cai, J.P.; Cheng, V.C.C.; Chen, H.; Hui, C.K.M.; Yuen, K.Y. A familial cluster of pneumonia associated with the 2019 novel coronavirus indicating person-to-person transmission: a study of a family cluster. Lancet 2020, 395, 514523, https://doi.org/10.1016/S0140-6736(20)30154-9.

12. Lam, T.T.Y.; Jia, N.; Zhang, Y.W.; Shum, M.H.H.; Jiang, J.F.; Zhu, H.C.; Tong, Y.G.; Shi, Y.X.; Ni, X.B.; Liao, Y.S.; Li, W.J.; Jiang, B.G.; Wei, W.; Yuan, T.T.; Zheng, K.; Cui, X.M.; Li, J.; Pei, G.Q.; Qiang, X.; Cheung, W.Y.M.; Li, L.F.; Sun, F.F.; Qin, S.; Huang, J.C.; Leung, G.M.; Holmes, E.C.; Hu, Y.L.; Guan, Y.; Cao, W.C. Identifying SARS-CoV-2 related coronaviruses in Malayan pangolins. Nature 2020, 583, 282285, https://doi.org/10.1038/s41586-020-2169-0.

13. Wang, D.; Hu, B.; Hu, C.; Zhu, F.; Liu, X.; Zhang, J.; Wang, B.; Xiang, H.; Cheng, Z.; Xiong, Y.; Zhao, Y.; Li, Y.; Wang, X.; Peng, Z. Clinical Characteristics of 138 Hospitalized Patients with 2019 Novel Coronavirus-Infected Pneumonia in Wuhan, China. JAMA 2020, 323, 1061-1069, https://doi.org/10.1001/jama.2020.1585.

14. Yuen, K.S.; Ye, Z.W.; Fung, S.Y.; Chan, C.P.; Jin, D.Y. SARS-CoV-2 and COVID-19: The most important research questions. Cell and Bioscience 2020, 10, 1-5, https://doi.org/10.1186/s13578-020-00404-4. 
15. Wu, J.T.; Leung, K.; Leung, G.M. Nowcasting and forecasting the potential domestic and international spread of the 2019-nCoV outbreak originating in Wuhan, China: a modelling study. Lancet 2020, 395, 689697, https://doi.org/10.1016/S0140-6736(20)30260-9.

16. Bai, Y.; Yao, L.; Wei, T.; Tian, F.; Jin, D.Y.; Chen, L.; Wang, M. Presumed Asymptomatic Carrier Transmission of COVID-19. JAMA 2020, 323, 1406-1407, https://doi.org/10.1001/jama.2020.2565.

17. Shih, H.I.; Wu, C.J.; Tu, Y.F.; Chi, C.Y. Fighting COVID-19: A quick review of diagnoses, therapies, and vaccines. Biomedical Journal 2020, 43, 341-354, https://doi.org/10.1016/j.bj.2020.05.021.

18. Gossner O. Group Testing Against Covid-19. Center for Research in Economics and Statistics. Working Papers 2020-02. Available from https://ideas.repec.org/p/crs/wpaper/2020-02.html.

19. Li, Z.; Yi, Y.; Luo, X.; Xiong, N.; Liu, Y.; Li, S.; Sun, R.; Wang, Y.; Hu, B.; Chen, W.; Zhang, Y.; Wang, J.; Huang, B.; Lin, Y.; Yang, J.; Cai, W.; Wang, X.; Cheng, J.; Chen, Z.; Sun, K.; Pan, W.; Zhan, Z.; Chen, L.; Ye, F. Development and clinical application of a rapid IgM-IgG combined antibody test for SARS-CoV2 infection diagnosis. Journal of Medical Virology 2020, 92, 1518-1524, https://doi.org/10.1002/jmv.25727.

20. Sheikhzadeh, E.; Eissa, S.; Ismail, A.; Zourob, M. Diagnostic techniques for COVID-19 and new developments. Talanta 2020, 220, https://doi.org/10.1016/j.talanta.2020.121392.

21. Chauhan S. Comprehensive review of coronavirus disease 2019 (COVID-19). Biomedical Journal 2020, 43, 334-340, https://doi.org/10.1016/j.bj.2020.05.023.

22. de Wit, E.; Feldmann, F.; Cronin, J.; Jordan, R.; Okumura, A.; Thomas, T.; Scott, D.; Cihlar, T.; Feldmann, H. Prophylactic and therapeutic remdesivir (GS-5734) treatment in the rhesus macaque model of MERS$\mathrm{CoV}$ infection. Proceedings of the National Academy of Sciences of the United States of America 2020, 117, 6771-6776, https://doi.org/10.1073/pnas.1922083117.

23. Caly, L.; Druce, J.D.; Catton, M.G.; Jans, D.A.; Wagstaff, K.M. The FDA-approved drug ivermectin inhibits the replication of SARS-CoV-2 in vitro. Antiviral Research 2020, 178, https://doi.org/10.1016/j.antiviral.2020.104787.

24. Jamshaid, H.; Zahid, F.; ud Din, I.; Zeb, A.; Choi, H.G.; Khan, G.M.; ud Din, F. Diagnostic and Treatment Strategies for COVID-19. An Official Journal of the American Association of Pharmaceutical Scientists 2020, 21, 1-14, https://doi.org/10.1208/s12249-020-01756-3.

25. Sheahan, T.P.; Sims, A.C.; Leist, S.R.; Schäfer, A.; Won, J.; Brown, A.J.; Montgomery, S.A.; Hogg, A.; Babusis, D.; Clarke, M.O.; Spahn, J.E.; Bauer, L.; Sellers, S.; Porter, D.; Feng, J.Y.; Cihlar, T.; Jordan, R.; Denison, M.R.; Baric, R.S. Comparative therapeutic efficacy of remdesivir and combination lopinavir, ritonavir, and interferon beta against MERS-CoV. Nature Communications 2020, 11, https://doi.org/10.1038/s41467-019-13940-6.

26. Gautret, P.; Lagier, J.C.; Parola, P.; Hoang, V.T.; Meddeb, L.; Mailhe, M.; Doudier, B.; Courjon, J.; Giordanengo, V.; Vieira V.E.; Dupont, H.T.; Honore, S.; Colson, P.; Chabriere, E.; Scola, B.L.; Rolain, J.M.; Brouqui, P.; Raoult, D. Hydroxychloroquine and azithromycin as a treatment of COVID-19: results of an open-label non-randomized clinical trial. International Journal of Antimicrobial Agents 2020, 56, https://doi.org/10.1016/j.ijantimicag.2020.105949.

27. Hung, I.F.N.; Lung, K.C.; Tso, E.Y.K.; Liu, R.; Chung, T.W.H.; Chu, M.Y.; Ng, Y.Y., Lo, J.; Chan, J.; Tam, A.R.; Shum, H.P.; Chan, V.; Wu, A.K.L.; Sin, K.M.; Leung, W.S.; Law, W.L.; Lung, D.C.; Sin, S.; Yeung, P.; Yip, C.C.Y.; Zhang, R.R.; Fung, A.Y.F.; Yan, E.Y.W.; Leung, K.H.; Ip, J.D.; Chu, A.W.H.; Chan, W.M.; Ng, A.C.K.; Lee, R.; Fung, K.; Yeung, A.; Wu, T.C.; Chan, J.W.M.; Yan, W.W.; Chan, W.M.; Chan, J.F.W.; Lie, A.K.W.; Tsang, O.T.Y.; Cheng, V.C.C.; Que, T.L.; Lau, C.S.; Chan, K.H.; To, K.K.W.; Yuen, K.Y. Triple combination of interferon beta-1b, lopinavir-ritonavir, and ribavirin in the treatment of patients admitted to hospital with COVID-19: an open-label, randomised, phase 2 trial. Lancet 2020, 395, 16951704,https://doi.org/10.1016/S0140-6736(20)31042-4.

28. Moore, C.M.; Pendse, D.; Emberton, M. Photodynamic therapy for prostate cancer - A review of current status and future promise. Nature Clinical Practice Urology 2009, 6, 18-30, https://doi.org/10.1038/ncpuro1274.

29. Hamblin, M.R.; Hasan, T. Photodynamic therapy: a new antimicrobial approach to infectious disease? Photochemical and Photobiological Sciences 2004, 3, 436-450. https://doi.org/10.1039/b311900a.

30. Maisch, T. Anti-microbial photodynamic therapy: Useful in the future? Lasers in Medical Science 2007, 22, 83-91, https://doi.org/10.1007/s10103-006-0409-7.

31. Jori, G.; Brown, S.B. Photosensitized inactivation of microorganisms. Photochemical and Photobiological Sciences 2004, 3, 403-405, https://doi.org/10.1039/b311904c.

32. Yin, R.; Agrawal, T.; Khan, U.; Gupta, G.K.; Rai, V.; Huang Y.Y.; Hamblin, M.R. Antimicrobial photodynamic inactivation in nanomedicine: small light strides against bad bugs. Nanomedicine 2015, 10, 2379-2404, https://doi.org/10.2217/nnm.15.67.

33. Lim, M.E.; Lee, Y.L.; Zhang, Y.; Chu, J.J.H. Photodynamic inactivation of viruses using upconversion nanoparticles. Biomaterials 2012, 33, 1912-1920, https://doi.org/10.1016/j.biomaterials.2011.11.033.

34. Almeida, R.D.; Manadas, B.J.; Carvalho, A.P.; Duarte, C.B. Intracellular signaling mechanisms in photodynamic therapy. Biochimica et Biophysica Acta (BBA) - Reviews in Cancer 2004, 1704, 59-86, https://doi.org/10.1016/j.bbcan.2004.05.003. 
35. Dolmans, D.E.J.G.J.; Fukumura, D.; Jain, R.K. Photodynamic therapy for cancer. Nature Reviews Cancer 2003, 3, 380-387, https://doi.org/10.1038/nrc1071.

36. Pathak, M.A. Mechanisms of psoralen photosensitization reactions. National Cancer Institute Monograph 1984, 66, 41-46.

37. Detty, M.R.; Gibson, S.L.; Wagner, S.J. Current clinical and preclinical photosensitizers for use in photodynamic therapy. Journal of Medicinal Chemistry 2004, 47, 3897-3915, https://doi.org/10.1021/jm040074b.

38. Zheng, H. A review of progress in clinical photodynamic therapy. Technology in Cancer Research and Treatment 2005, 4, 283-293,https://dx.doi.org/10.1177\%2F153303460500400308.

39. Gao, X.; Cui, Y.; Levenson, R.M.; Chung, L.W.K.; Nie, S. In vivo cancer targeting and imaging with semiconductor quantum dots. Nature Biotechnology 2004, 22, 969-976,https://doi.org/10.1038/nbt994.

40. Genger, U.R.; Grabolle, M.; Jaricot S.C.; Nitschke R.; Nann, T. Quantum dots versus organic dyes as fluorescent labels. Nature Methods 2008, 5, 763-775,https://doi.org/10.1038/nmeth.1248.

41. Ye, L.; Yong, K.T.; Liu, L.; Roy, I.; Hu, R.; Zhu, J.; Cai, H.; Law, W.C.; Liu, J.; Wang, K.; Liu, J.; Liu, Y.; Hu, Y.; Zhang, X.; Swihart, M.T.; Prasad, P.N. A pilot study in non-human primates shows no adverse response to intravenous injection of quantum dots. Nature Nanotechnology 2012, 7, 453458,https://doi.org/10.1038/nnano.2012.74.

42. Samia, A.C.S.; Chen, X.; Burda, C. Semiconductor Quantum Dots for Photodynamic Therapy. Journal of the American Chemical Society 2003, 125, 15736-15737, https://doi.org/10.1021/ja0386905.

43. Tsay, J.M.; Trzoss, M.; Shi, L.; Kong, X.; Selke, M.; Jung, M.E.; Weiss S. Singlet Oxygen Production by Peptide-Coated Quantum Dot - Photosensitizer Conjugates. Journal of the American Chemical Society 2007, 129, 6865-6871, https://doi.org/10.1021/ja070713i.

44. Ge, J.; Lan, M.; Zhou, B.; Liu, W.; Guo, L.; Wang, H.; Jia, Q.; Niu, G.; Huang, X.; Zhou, H.; Meng, X.; Wang, P.; Lee, C.S.; Zhang, W.; Han, X. A graphene quantum dot photodynamic therapy agent with high singlet oxygen generation. Nature Communications 2014, 5, 1-8, https://doi.org/10.1038/ncomms5596.

45. Wiehe, A.; O’Brien, J.M.; Senge, M.O. Trends and targets in antiviral phototherapy. Photochemical and Photobiological Sciences 2019, 18, 2565-2612, https://doi.org/10.1039/c9pp00211a.

46. Singh, R.K.; Rai, D.; Yadav, D.; Bhargava, A.; Balzarini, J.; Clercq, E.D. Synthesis, antibacterial and antiviral properties of curcumin bioconjugates bearing dipeptide, fatty acids and folic acid. European Jornal of Medicinal Chemistry 2010, 45, 1078-1086, https://doi.org/10.1016/j.ejmech.2009.12.002.

47. Lin, L.; Hanson, C.V.; Alter, H.J.; Jauvin, V.; Bernard, K.A.; Murthy, K.K.; Metzel, P.; Corash, L. Inactivation of viruses in platelet concentrates by photochemical treatment with amotosalen and longwavelength ultraviolet light. Transfusion 2005, 45, 580-90, https://doi.org/10.1111/j.00411132.2005.04316.x.

48. Schneider, K.; Edwards L.W.; Embrey M.L.; Walker, E.; Sun, P.; Ondov, B.; Wyman, T.H.; Rosovitz, M.J.; Bohn, S.S.; Burans, J.; Kochel, T. Psoralen inactivation of viruses: A process for the safe manipulation of viral antigen and nucleic acid. Viruses 2015, 7, 5875-5888, https://dx.doi.org/10.3390\%2Fv7112912.

49. Keil, S.D.; Bowen, R.; Marschner, S. Inactivation of Middle East respiratory syndrome coronavirus (MERS$\mathrm{CoV}$ ) in plasma products using a riboflavin-based and ultraviolet light-based photochemical treatment. Transfusion 2016, 56, 2948-2952, https://doi.org/10.1111/trf.13860.

50. Han, W.; Zhang, P.H.; Cao, W.C.; Yang, D.L.; Taira, S.; Okamoto, Y.; Arai, J.I.; Yan, X.Y. The Inactivation Effect of Photocatalytic Titanium Apatite Filter on SARS Virus. Progress in Biochemistry and Biophysics 2004, 31, 982-985.

51. Kendall, C.A.; Morton, C.A. Photodynamic Therapy for the Treatment of Skin Disease. Technology in Cancer Research and Treatment 2003, 2, 283-288, https://doi.org/10.1177\%2F153303460300200402.

52. Perni, S.; Prokopovich, P.; Pratten, J.; Parkin, I.P.; Wilson, M. Nanoparticles: Their potential use in antibacterial photodynamic therapy. Photochemical and Photobiological Sciences 2011, 10, 712-20, https://doi.org/10.1039/c0pp00360c.

53. Alarcón E.; Edwards, A.M.; Aspée, A.; Borsarelli, C.D.; Lissi, E.A. Photophysics and photochemistry of rose bengal bound to human serum albumin. Photochemical and Photobiological Sciences 2009, 8, 933943, https://doi.org/10.1039/b901056d.

54. Guo, Y.; Rogelj, S.; Zhang, P. Rose Bengal-decorated silica nanoparticles as photosensitizers for inactivation of gram-positive bacteria. Nanotechnology 2010, 21, https://doi.org/10.1088/0957-4484/21/6/065102.

55. Suppan, P. Chemistry and Light. 1994;https://doi.org/10.1039/9781847550439.

56. Fujishima, A.; Honda, K. Electrochemical Photolysis of Water at a Semiconductor Electrode. Nature 1972, 238, 37-38, https://doi.org/10.1038/238037a0.

57. Mills, A.; Hunte S.L. An overview of semiconductor photocatalysis. Journal of Photochemistry and Photobiology A: Chemistry 1997, 108, 1-35, https://doi.org/10.1016/S1010-6030(97)00118-4.

58. Zan, L.; Fa, W.; Peng, T.; Gong, Z.K. Photocatalysis effect of nanometer TiO2 and TiO2-coated ceramic plate on Hepatitis B virus. Journal of Photochemistry and Photobiology B: Biology 2007, 86, 165-169, https://doi.org/10.1016/j.jphotobiol.2006.09.002. 
59. Gurunathan, S.; Qasim, M.; Choi, Y.; Do, J.T.; Park, C.; Hong, K.; Kim, J.H.; Song, H. Antiviral potential of nanoparticles - can nanoparticles fight against coronaviruses? Nanomaterials 2020, 10, 129,https://doi.org/10.3390/nano10091645.

60. Du, T.; Liang, J.; Dong, N.; Liu, L.; Fang, L.; Xiao, S.; Han, H. Carbon dots as inhibitors of virus by activation of type I interferon response. Carbon 2016, 110, 278-285, https://doi.org/10.1016/j.carbon.2016.09.032.

61. Barras, A.; Pagneux, Q.; Sane, F.; Wang, Q.; Boukherroub, R.; Hober, D.; Szunerits S. High Efficiency of Functional Carbon Nanodots as Entry Inhibitors of Herpes Simplex Virus Type 1. ACS Applied Materials and Interfaces 2016, 8, 9004-13, https://doi.org/10.1021/acsami.6b01681.

62. Fahmi, M.Z.; Sukmayani, W.; Khairunisa, S.Q.; Witaningrum, A.M.; Indriati, D.W.; Matondang, M.Q.Y.; Chang, J.Y.; Kotaki, T.; Kameoka, M. Design of boronic acid-attributed carbon dots on inhibits HIV-1 entry. RSC Advances 2016, 6, 92996-93002, https://doi.org/10.1039/c6ra21062g.

63. Łoczechin, A.; Séron, K.; Barras, A.; Giovanelli, E.; Belouzard, S.; Chen, Y.T.; Nolte, N.M.; Boukherroub, R.; Dobuisson, J.; Szunerits S. Functional Carbon Quantum Dots as Medical Countermeasures to Human Coronavirus. ACS Applied Materials and Interfaces 2019, 11, 42964-42974, https://doi.org/10.1021/acsami.9b15032.

64. Banerjee, I.; Douaisi, M.P.; Mondal, D.; Kane, R.S. Light-activated nanotubeporphyrin conjugates as effective antiviral agents. Nanotechnology 2012, 23, https://doi.org/10.1088/0957-4484/23/10/105101.

65. Oza, G.; Pandey, S.; Gupta, A.; Shinde, S.; Mewada, A.; Jagadale, P.; Sharon, M.; Sharon, M. Photocatalysisassisted water filtration: Using TiO2-coated vertically aligned multi-walled carbon nanotube array for removal of Escherichia coli O157:H7. Materials Science and Engineering: C 2013, 33, 4392-4400, https://doi.org/10.1016/j.msec.2013.06.039.

66. Zhou, L.; Zhou, L.; Wei, S.; Ge, X.; Zhou, J.; Jiang, H.; Li, F.; Shen. J. Combination of chemotherapy and photodynamic therapy using graphene oxide as drug delivery system. Journal of Photochemistry and Photobiology B: Biology 2014, 135, 7-16, https://doi.org/10.1016/j.jphotobiol.2014.04.010.

67. Sahu, A., Choi, W.I.; Lee, J.H.; Tae, G. Graphene oxide mediated delivery of methylene blue for combined photodynamic and photothermal therapy. Biomaterials 2013, 34, 6239-6248, https://doi.org/10.1016/j.biomaterials.2013.04.066.

68. Ristic, B.Z.; Milenkovic, M.M.; Dakic, I.R.; Markovic, B.M.T.; Milosavljevic, M.S.; Budimir, M.D.; Paunovic, V.G.; Dramicanin, M.D.; Markovic, Z.M.; Trajkovic, V.S. Photodynamic antibacterial effect of graphene quantum dots. Biomaterials https://doi.org/10.1016/j.biomaterials.2014.02.014.

69. Song, Z.; Wang, X.; Zhu, G.; Nian, Q.; Zhou, H.; Yang, D.; Qin, C.; Tang, R. Virus capture and destruction by label-free graphene oxide for detection and disinfection applications. Small 2015, 11, 17711776,https://doi.org/10.1002/smll.201401706.

70. Gianvincenzo, P.D.; Marradi, M.; Martínez-Ávila, O.M.; Bedoya, L.M.; Alcamí, J.; Penadés, S. Gold nanoparticles capped with sulfate-ended ligands as anti-HIV agents. Bioorganic and Medicinal Chemistry Letters 2010, 20, 2718-2721, https://doi.org/10.1016/j.bmcl.2010.03.079.

71. Lara, H.H.; Ayala-Nuñez, N.V.; Ixtepan-Turrent, L.; Rodriguez-Padilla, C. Mode of antiviral action of silver nanoparticles against HIV-1. Journal of Nanobiotechnology 2010, 8, 1-10, https://doi.org/10.1186/14773155-8-1.

72. Baram-Pinto, D.; Shukla, S.; Perkas, N.; Gedanken, A.; Sarid, R. Inhibition of herpes simplex virus type 1 infection by silver nanoparticles capped with mercaptoethane sulfonate. BioconjugateChemistry 2009, 20, 1497-502, https://doi.org/10.1021/bc900215b.

73. Lu, L.; Sun R.W.Y.; Chen, R.; Hui C.K.; Ho, C.M.; Luk, J.M.; Lau, G.K.K.; Che, C.M. Silver nanoparticles inhibit hepatitis B virus replication. Antiviral Therapy 2008, 13, 253-262.

74. Sun, L.; Singh, A.K.; Vig, K.; Pillai, S.R.; Singh, S.R. Silver nanoparticles inhibit replication of respiratory syncytial virus. Journal of Biomedical Nanotechnology 2008, 4, 149-158.

75. Hitzky E.R.; Darder, M.; Wicklein, B.; Garcia, C.R.; Sampedro, R.M.; del Real G, Aranda P. Nanotechnology Responses to COVID-19. Advanced Healthcare Materials 2020, 9, 1-26, https://doi.org/10.1002/adhm.202000979.

76. Haase, M.; Schäfer, H. Upconverting nanoparticles. Angewandte Chemie - International Edition 2011, 50, 5808-5829, https://doi.org/10.1002/anie.201005159.

77. Wainwright, M. Local treatment of viral disease using photodynamic therapy. International Journal of Antimicrobial Agents 2003, 21, 510-520,https://doi.org/10.1016/s0924-8579(03)00035-9.

78. Huang, Y.Y.; Sharma, S.K.; Dai, T.; Chung, H.; Yaroslavsky, A.; Garcia-Diaz, M.; Chang, J.; Chinag, L.Y.; Hamblin, M.R. Can nanotechnology potentiate photodynamic therapy? Nanotechnology Reviews 2012, 1, 111-146.

79. Dougherty, T.J.; Gomer, C.J.; Henderson, B.W.; Jori, G.; Kessel, D.; Korbelik, M.; Moan, J.; Peng, Q. Photodynamic therapy. Journal of the National Cancer Institute 1998, 90, 889-905, https://doi.org/10.1093/jnci/90.12.889.

80. Wainwright, M. Photodynamic Antimicrobial Chemotherapy (PACT). Journal of Antimicrobial Chemotherapy 1998, 42, 13-28, https://doi.org/10.1093/jac/42.1.13. 
81. Grzybowski, A.; Pietrzak, K. From patient to discoverer — Niels Ryberg Finsen ( $1860-1904)$ - the founder of phototherapy in dermatology. Clinics in Dermatology 2012, 30, 451-455, https://doi.org/10.1016/j.clindermatol.2011.11.019.

82. Maisch, T. Resistance in antimicrobial photodynamic inactivation of bacteria. Photochemical and Photobiological Sciences 2015, 14, 1518-1526,https://doi.org/10.1039/c5pp00037h.

83. Kwitniewski, M.; Juzeniene, A.; Glosnicka, R.; Moan, J. Immunotherapy: A way to improve the therapeutic outcome of photodynamic therapy? Photochemical and Photobiological Sciences 2008, 7, 1011-1017, https://doi.org/10.1039/B806710D.

84. Straten, D.V.; Mashayekhi, V.; Bruijn, H.S.D.; Oliveira, S.; Robinson, D.J. Oncologic photodynamic therapy: Basic principles, current clinical status and future directions. Cancers 2017, 9, 1-54, https://doi.org/10.3390/cancers9020019.

85. Trushina, O.I.; Novikova, E.G.; Sokolov, V.V.; Filonenko, E.V.; Chissov, V.I.; Vorozhtsov, G.N. Photodynamic therapy of virus-associated precancer and early stages cancer of cervix uteri. Photodiagnosis and Photodynamic Therapy 2008, 5, 256-259,https://doi.org/10.1016/j.pdpdt.2008.09.005.

86. Mrázová, V.; Kúdelová, M.; Smolinská, M.; Nováková, E.; Šupolíková, M.; Vrbová, M.; Golais, F. Transformation of Cells by Photoinactivated Murine Gamma-Herpesvirus 68 during Nonproductive and Quiescent Infection. Intervirology 2017, 60, 61-68, https://doi.org/10.1159/000479373.

87. Sobotta, L.; Mrugalska, P.S.; Mielcarek J.; Goslinski, T.; Balzarini, J. Photosensitizers Mediated Photodynamic Inactivation Against Virus Particles. Mini-Reviews in Medicinal Chemistry 2015, 15, 503521. https://doi.org/10.2174/1389557515666150415151505.

88. Costa, L.; Faustino, M.A.F.; Neves, M.G.P.M.S.; Cunha, Â.; Almeida, A. Photodynamic inactivation of mammalian viruses and bacteriophages. Viruses 2012, 4, 1034-1074, https://dx.doi.org/10.3390\%2Fv4071034.

89. Käsermann, F.; Kempf, C. Photodynamic inactivation of enveloped viruses by buckminsterfullerene. Antiviral Research 1997, 34, 65-70, https://doi.org/10.1016/s0166-3542(96)01207-7.

90. Lorizate, M.; Kräusslich, H.G. Role of lipids in virus replication. Cold Spring Harbor Perspectives in Biology 2011, 3, 1-20, https://dx.doi.org/10.1101\%2Fcshperspect.a004820.

91. Hossain, M.; Suresh Kumar, G. DNA intercalation of methylene blue and quinacrine: New insights into base and sequence specificity from structural and thermodynamic studies with polynucleotides. Molecular Biosystems 2009, 5, 1311-1322, https://doi.org/10.1039/B909563B.

92. Vardevanyan, P.O.; Antonyan, A.P.; Parsadanyan, M.A.; Shahinyan, M.A.; Hambardzumyan, L.A. Mechanisms for Binding between Methylene Blue and DNA. Journal of Applied Spectroscopy 2013, 80, 595-599,https://doi.org/10.1007/s10812-013-9811-7.

93. Girotti, A.W. Photosensitized oxidation of membrane lipids: Reaction pathways, cytotoxic effects, and cytoprotective mechanisms. Journal of Photochemistry and Photobiology B: Biology 2001, 63, 103-13, https://doi.org/10.1016/s1011-1344(01)00207-X.

94. Baptista, M.S.; Cadet, J.; Mascio, P.D.; Ghogare, A.A.; Greer, A.; Hamblin, M.R.; Lorente, C.; Nunez, S.C.; Ribeiro, M.S.; Thomas, A.H., Vignoni, M.; Yoshimura, T.M. Type I and Type II Photosensitized Oxidation Reactions: Guidelines and Mechanistic Pathways. Photochemistry and Photobiology 2017, 93, 912-919, https://doi.org/10.1111/php.12716.

95. Majiya, H.; Adeyemi, O.O.; Stonehouse, N.J.; Millner, P. Photodynamic inactivation of bacteriophage MS2: The A-protein is the target of virus inactivation. Journal of Photochemistry and Photobiology B: Biology 2018, 178, 404-411, https://doi.org/10.1016/j.jphotobiol.2017.11.032.

96. Pinna, D.; Johannes, A.S.; Clementi, M.; Poli, G.; Rossini, S.; Lin, L.; Vicenzi E. Amotosalen photochemical inactivation of severe acute respiratory syndrome coronavirus in human platelet concentrates. Transfusion Medicine 2005, 15, 269-276, https://doi.org/10.1111/j.0958-7578.2005.00588.x.

97. Taher, M.M.; Lammering, G.M.; Hershey, C.M.; Valerie, K.C. Mood-enhancing antidepressant St. John's wort inhibits the activation of human immunodeficiency virus gene expression by ultraviolet light. IUBMB Life 2002, 54, 357-64, https://doi.org/10.1080/15216540216039.

98. Shih, C.M.; Wu, C.H.; Wu, W.J.; Hsiao, Y.M.; Ko, J.L. Hypericin inhibits hepatitis C virus replication via deacetylation and down-regulation of heme oxygenase-1. Phytomedicine 2018, 46, 193-198, https://doi.org/10.1016/j.phymed.2017.08.009.

99. Kessel, D. Exploring Modes of Photokilling by Hypericin. Photochemistry and Photobiology 2020, 96, 1101-1104, https://doi.org/10.1111/php.13275.

100. Carpenter, S.; Kraus, G.A. Photosensitization is required for inactivation of equine infectious anemia virus by hypericin. Photochemistry and Photobiology 1991, 53, 169-174, https://doi.org/10.1111/j.17511097.1991.tb03919.x.

101. Miskovsky, P. Hypericin - A New Antiviral and Antitumor Photosensitizer: Mechanism of Action and Interaction with Biological Macromolecules. Current Drug Targets2002, 3, 55-84, https://doi.org/10.2174/1389450023348091.

102. Birt, D.F.; Widrlechner, M.P.; Hammer, K.D.P.; Hillwig, M.L.; Wei, J.; Kraus, G.A.; Murphy, P.A.; McCoy, J.A.; Wurtele, E.S.; Neighbors, J.D.; Wiemer, D.F.; Maury, W.J.; Price, J.P. Hypericum in infection: 
Identification of antiviral and anti-inflammatory constituents. Pharmaceutical Biology 2009, 47, 774-82, https://dx.doi.org/10.1080\%2F13880200902988645.

103. Degar, S.; Prince, A.M.; Pascual, D.; Lavie, G.; Levin, B.; Mazur, Y.; Lavie, D.; Ehrlich, L.S.; Carter, C.; Meruelo, D. Inactivation of the Human Immunodeficiency Virus by Hypericin: Evidence for Photochemical Alterations of p24 and a Block in Uncoating. AIDS Research and Human Retroviruses 1992, 8, 1929-1936, https://doi.org/10.1089/aid.1992.8.1929.

104. Lenard, J.; Rabsont, A.; Vanderoef, R. Photodynamic inactivation of infectivity of human immunodeficiency virus and other enveloped viruses using hypericin and rose bengal: Inhibition of fusion and syncytia formation. Proceedings of the National Academy of Sciences of the United States of America 1993, 90, 158162, https://doi.org/10.1073/pnas.90.1.158.

105. Yip, L.; Hudson, J.B.; Kowalik, E.G.; Zalkow, L.H.; Towers, G.H.N. Antiviral activity of a derivative of the photosensitive compound hypericin. Phytomedicine 1996, 3, 185-190, https://doi.org/10.1016/S09447113(96)80034-1.

106. Hudson, J.B.; Delaey, E.; de Witte, P.A. Bromohypericins are potent photoactive antiviral agents. Photochemistry and Photobiology 1999, 70, 820-822, https://doi.org/10.1111/j.1751-1097.1999.tb08288.x.

107. Du, X.; Xiao, R.; Fu, H.; Yuan, Z.; Zhang, W.; Yin, L.; He, C.; Li, C.; Zhou, J.; Liu, G.; Shu, G.; Chen, Z. Hypericin-loaded graphene oxide protects ducks against a novel duck reovirus. Material Science and Engineering: C 2019, 105, https://doi.org/10.1016/j.msec.2019.110052.

108. Xu, L.; Zhang, X.; Cheng, W.; Wang, Y.; Yi, K.; Wang, Z.; Zhang, Y.; Shao, L.; Zhao, T. Hypericinphotodynamic therapy inhibits the growth of adult T-cell leukemia cells through induction of apoptosis and suppression of viral transcription. Retrovirology 2019, 16, 1-13, https://doi.org/10.1186/s12977-019-04670 .

109. Chen, H.; Muhammad, I.; Zhang, Y.; Ren, Y.; Zhang, R.; Huang, X.; Diao, L.; Liu, H.; Li, X.; Sun, X.; Abbas, G.; Li, G. Antiviral activity against infectious bronchitis virus and bioactive components of Hypericum perforatum L. Frontiers in Pharmacology 2019, 10, 1-22, https://doi.org/10.3389/fphar.2019.01272.

110. Chen, H.; Feng, R.; Muhammad, I.; Abbas, G.; Zhang, Y.; Ren, Y.; Huang, X.; Zhang, R.; Diao, L.; Wang, $\mathrm{X}$; $\mathrm{Li}, \mathrm{G}$. Protective effects of hypericin against infectious bronchitis virus induced apoptosis and reactive oxygen species in chicken embryo kidney cells. Poultry Science 2019, 98, 6367-637, https://dx.doi.org/10.3382\%2Fps\%2Fpez465.

111. Talele, T.T.; Khedkar, S.A.; Rigby, A. Successful Applications of Computer Aided Drug Discovery: Moving Drugs from Concept to the Clinic. Current Topics in Medicinal Chemistry 2010, 10, 127-141. https://doi.org/10.2174/156802610790232251.

112. Hirakawa, K.; Yoshida, M.; Oikawa, S.; Kawanishi, S. Base Oxidation at 5' Site of GG Sequence in Doublestranded DNA Induced by UVA in the Presence of Xanthone Analogues: Relationship Between the DNAdamaging Abilities of Photosensitizers and Their HOMO Energies. Photochemistry and Photobiology 2003, 77, 349-355, https://doi.org/10.1562/0031-8655(2003)077\%3C0349:boasog\%3E2.0.co;2.

113. Hirakawa, K. Computational Chemistry for Photosensitizer Design and Investigation of DNA Damage. Frontiers in Computational Chemistry 2015, 2, 27-70, https://doi.org/10.2174/9781608059782115020004.

114. Eriksson, E.S.E.; Guedes, R.C., Eriksson, L.A. Redox and Debromination Reactions of Brominated Hypericin. International Journal of Quantum Chemistry 2008, 108, 19211929,https://doi.org/10.1002/qua.21689.

115. Eriksson, E.S.E.; dos Santos, D.J.V.A.; Guedes, R.C.; Eriksson, L.A. Properties and permeability of hypericin and brominated hypericin in lipid membranes. Journal of Chemical Theory and Computation 2009, 5, 3139-3149, https://doi.org/10.1021/ct9002702.

116. Eriksson, E.S.E.; Eriksson, L.A. The influence of cholesterol on the properties and permeability of hypericin derivatives in lipid membranes. Journal of Chemical Theory and Computation 2011, 7, 560-574, https://doi.org/10.1021/ct100528u.

117. Miskovsky, P.; Hritz, J.; Cortes, S.S.; Fabriciova, G.; Ulicny, J.; Chinsky, L. Interaction of Hypericin with Serum Albumins: Surface-enhanced Raman Spectroscopy, Resonance Raman Spectroscopy and Molecular Modeling Study. Photochemistry and Photobiology 2001, 74, 172-183.

118. Delcanale, P.; Amigo, B.R.; Jiménez J.J.; Luque, F.J.; Abbruzzetti, S.; Agut, M.; Nonell, S.; Viappiani, C. Tuning the local solvent composition at a drug carrier surface: the effect of dimethyl sulfoxide/water mixture on the photofunctional properties of hypericin- $\beta$-lactoglobulin complexes. Journal of Materials Chemistry B 2017, 5, 1633-1641. https://doi.org/10.1039/C7TB00081B.

119. Islam, R.; Parves, M.R.; Paul, A.S.; Uddin, N.; Rahman, M.S.; Mamun, A.A., Hossain, M.N.; Ali, M.A.; Halim, M.A. A Molecular Modeling Approach to Identify Effective Antiviral Phytochemicals against the Main Protease of SARS-CoV-2. Journal of Biomolecular Structure and Dynamics 2020, 1-20, https://doi.org/10.1080/07391102.2020.1761883.

120. Agrawal, A.; Jain, N.K.; Kumar, N.; Kulkarni, G.T. Molecular Docking Study to Identify Potential Inhibitor of COVID-19 Main Protease Enzyme: An In-Silico Approach. ChemRxiv 2020, http://doi.org/10.26434/chemrxiv.12170904.v1. 
121. Micholas, S.; Jeremy, C.S. Repurposing Therapeutics for COVID-19: Supercomputer-Based Docking to the SARS-CoV-2 Viral Spike Protein and Viral Spike Protein-Human ACE2 Interface. ChemRxiv 2020, https://doi.org/10.26434/chemrxiv.11871402.

122. Ekins, S.; Honeycutt, J.D.; Metz, J.T. Evolving molecules using multi-objective optimization: Applying to ADME/Tox. Drug Discovery Today 2010, 15, 451-460,https://doi.org/10.1016/j.drudis.2010.04.003.

123. Wenzel, J.; Matter, H.; Schmidt, F. Predictive Multitask Deep Neural Network Models for ADME-Tox Properties: Learning from Large Data Sets. Journal of Chemical Information and Modeling 2019, 59, 12531268, https://doi.org/10.1021/acs.jcim.8b00785.

124. Schmidt, F.; Wenzel, J.; Halland, N.; Güssregen, S.; Delafoy, L.; Czich, A. Computational Investigation of Drug Phototoxicity: Photosafety Assessment, Photo-Toxophore Identification, and Machine Learning. Chemical Research in Toxicology 2019, 32, 2338-2352, https://doi.org/10.1021/acs.chemrestox.9b00338.

125. Becke, A.D. Density-functional thermochemistry. III. The role of exact exchange. The Journal of Chemical Physics 1993, 98, 5648-5652,https://doi.org/10.1063/1.464913.

126. Dreuw, A.; Gordon, M.H. Single-reference ab initio methods for the calculation of excited states of large molecules. Chemical Reviews 2005, 105, 4009-4037, https://doi.org/10.1021/cr0505627.

127. Ringeissen, S.; Marrot, L.; Note, R.; Labarussiat, A.; Imbert, S.; Todorov, M.; Makenyan, O.; Meunier, J.R. Development of a mechanistic SAR model for the detection of phototoxic chemicals and use in an integrated testing strategy. Toxicology in Vitro 2011, 25, 324-334,https://doi.org/10.1016/j.tiv.2010.09.017.

128. Haranosono, Y.; Kurata, M.; Sakaki, H. Establishment of an in silico phototoxicity prediction method by combining descriptors related to photo-absorption and photo-reaction. The Journal of Toxicological Sciences 2014, 39, 655-664, https://doi.org/10.2131/jts.39.655.

129. Ekins, S.; Puhl, A.C.; Zorn, K.M.; Lane, T.R.; Russo, D.P.; Klein, J.J.; Hickey, A.J., Clark, A.M. Exploiting machine learning for end-to-end drug discovery and development. Nature Materials 2019, 18, 435-441, https://doi.org/10.1038/s41563-019-0338-z.

130. Ceridono, M.; Tellner, P.; Bauer, D.; Barroso, J.; Alépée, N.; Corvi, R.; Smedt, AD.; Fellows, M.D.; Gibbs, N.K.; Heisler, E.; Jacobs, A.; Jirova, D.; Jones, D.; Kandarova, H.; Kasper, P.; Akunda, J.K.; Krul, C.; Learn, D.; Wilcox, P. The 3T3 neutral red uptake phototoxicity test: Practical experience and implications for phototoxicity testing - The report of an ECVAM-EFPIA workshop. Regulatory Toxicology and Pharmacology 2012, 63, 480-488, https://doi.org/10.1016/j.yrtph.2012.06.001.

131. Netzlaff, F.; Lehr, C.M.; Wertz, P.W.; Schaefer, U.F. The human epidermis models EpiSkin ${ }^{\circledR}$, SkinEthic ${ }^{\circledR}$ and EpiDerm®: An evaluation of morphology and their suitability for testing phototoxicity, irritancy, corrosivity, and substance transport. European Journal of Pharmaceutics and Biopharmaceutics 2005, 60, 167-178, https://doi.org/10.1016/j.ejpb.2005.03.004.

132. Onoue, S.; Hosoi, K.; Wakuri, S.; Iwase, Y.; Yamamoto, T.; Matsuoka, N.; Nakamura, K.; Toda, T.; Takagi, H.; Osaki, N.; Matsumoto, Y.; Kawakami, S.; Seto, Y.; Kato, M.; Yamada, S.; Ohno, Y.; Kojima, H. Establishment and intra-/inter-laboratory validation of a standard protocol of reactive oxygen species assay for chemical photosafety evaluation. Journal of Applied Toxicology 2013, 33, 1241-1250, https://doi.org/10.1002/jat.2776.

133. Onoue, S.; Hosoi, K.; Toda, T.; Takagi, H.; Osaki, N.; Matsumoto, Y.; Kawakami, S.; Wakuri, S.; Iwase, Y.; Yamamoto, T.; Nakamura, K.; Ohno, Y.; Kojima, H. Intra-/inter-laboratory validation study on reactive oxygen species assay for chemical photosafety evaluation using two different solar simulators. Toxicology in Vitro 2014, 28, 515-523, https://doi.org/10.1016/j.tiv.2013.11.014.

134. Wolfsen, H.C.; Ng C.S. Cutaneous consequences of photodynamic therapy. Cutis, 2002, 69, 140-142.

135. Engesæter, B.; Tveito, S.; Bonsted, A.; Engebraaten, O.; Berg, K.; Mælandsmo, G.M. Photochemical treatment with endosomally localized photosensitizers enhances the number of adenoviruses in the nucleus. Journal of Gene Medicine 2006, 8, 707-718,https://doi.org/10.1002/jgm.902.

136. Smetana, Z.; Ben-Hur, E.; Mendelson, E.; Salzberg, S.; Wagner, P.; Malik, Z. Herpes simplex virus proteins are damaged following photodynamic inactivation with phthalocyanines. Journal of Photochemistry and Photobiology B: Biology 1998, 44, 77-83, https://doi.org/10.1016/S1011-1344(98)00124-9.

137. Abe, H.; Ikebuchi, K.; Wagner, S.J.; Kuwabara, M.; Kamo, N.; Sekiguchi, S. Potential Involvement of Both Type I and Type II Mechanisms in M13 Virus Inactivation by Methylene Blue Photosensitization. Photochemistry and Photobiology 1997, 66, 204-208, https://doi.org/10.1111/j.1751-1097.1997.tb08644.x.

138. Rywkin, S.; Lenny, L.; Goldstein, J.; Geacintov, N.E.; Nunno, H.M.; Horowitz, B. Importance of Type I and Type Ii Mechanisms in the Photodynamic Inactivation of Viruses in Blood With Aluminum Phthalocyanine Derivatives. Photochemistry and Photobiology 1992, 56, 463-469, https://doi.org/10.1111/j.17511097.1992.tb02189.x.

139. Costa, L.; Faustino, M.A.F.; Tomé, J.P.C.; Neves, M.G.P.M.S.; Tomé, A.C.; Cavaleiro, J.A.S.; Cunha, A.; Almeida, A. Involvement of type I and type II mechanisms on the photoinactivation of non-enveloped DN and RNA bacteriophages. Journal of Photochemistry and Photobiology B: Biology 2013, 120, 10-16, https://doi.org/10.1016/j.jphotobiol.2013.01.005.

140. Jarvi, M.T.; Niedre, M.J.; Patterson, M.S.; Wilson, B.C. The influence of oxygen depletion and photosensitizer triplet-state dynamics during photodynamic therapy on accurate singlet oxygen 
luminescence monitoring and analysis of treatment dose response. Photochemistry and Photobiology 2011, 87, 223-234, https://doi.org/10.1111/j.1751-1097.2010.00851.x.

141. Woodhams, J.H.; MacRobert, A.J.; Bown, S.G. The role of oxygen monitoring during photodynamic therapy and its potential for treatment dosimetry. Photochemistry and Photobiological Sciences2007, 6,1234-1245, https://doi.org/10.1039/b709644e.

142. Looft, A.; Pfitzner, M.; Preuß, A.; Röder, B. In vivo singlet molecular oxygen measurements: Sensitive to changes in oxygen saturation during PDT. Photodiagnosis and Photodynamic Therapy 2018, 23, 325-330, https://doi.org/10.1016/j.pdpdt.2018.07.006.

143. Ogilby, P.R. Singlet oxygen: There is indeed something new under the sun. Chemical Society Reviews 2010, 39, 3181-3209, https://doi.org/10.1039/b926014p.

144. Kanofsky, J.R. Measurement of singlet-oxygen in vivo: Progress and pitfalls. Photochemistry and Photobiology 2011, 87, 14-17, https://doi.org/10.1111/j.1751-1097.2010.00855.x.

145. Via, L.D.; Magno, S.M. Photochemotherapy in the treatment of cancer. Current Medicinal Chemistry 2001, 8, 1405-1418, https://doi.org/10.2174/0929867013372076. 